Tetrahedron Letters

journal homepage: www.elsevier.com

\title{
Synthesis of Dual-Emissive Organometallic Complexes Containing Heterogeneous Metal Elements
}

\author{
Amane Hirose, Kazuo Tanaka*, Kenji Tamashima, Yoshiki Chujo* \\ Department of Polymer Chemistry, Graduate School of Engineering, Kyoto University, Katsura, Nishikyo-ku, Kyoto 615-8510, Japan
}

\section{ARTICLE INFO}

\section{Article history:}

Received

Received in revised form

Accepted

Available online

Keywords:

Organoboron complex

Diketonate

Platinum complex

Dual emission

\section{ABSTRACT}

\begin{abstract}
We present the dual-emissive dye containing heterogeneous organometallic units. The diad ligand composed of two diketonate moieties linked by fluorene was synthesized. By introducing boron and platinum elements, the emissive molecules were obtained. From optical measurements, it was confirmed that the boron and the platinum-containing diads showed the emissions from the charge transfer and the triplet $\pi-\pi^{*}$ ligand centered transitions, respectively. Next, to observe these fluorescence and phosphorescence properties from the dye molecule, the diad composed of boron and platinum diketonates linked by the fluorene unit were prepared. Finally, the dual emission containing fluorescence from the boron complex and phosphorescence from the platinum complex was simultaneously observed.
\end{abstract}

2009 Elsevier Ltd. All rights reserved.
Dual-emissive materials have attracted attention because of their large potential for organic opto and/or electronic devices such as displays and optical chemosensors. For example, by loading the red, green, and blue chromophores into the polymeric matrices, the white-light emissive materials can be obtained. ${ }^{1-3}$ By modulating the feed ratio of each dye, the precise color tuning was accomplished. In these mixture systems, the suppression of the energy transfer is critical for obtaining the desired color and improving device efficiencies. As another instance, the optical sensor based on the fluorescent artificial nucleobase was presented for monitoring the structural alteration of DNA. ${ }^{4}$ The suppression of the molecular motion at the excited state provided the dual emission from the solution, resulting in the color change. Fräser et al. synthesized the dual-emissive molecules having both fluorescence and phosphorescence and successfully used them as the ratiometric oxygen sensor in the cells. ${ }^{5,6}$ From the intensity ratio between fluorescence and phosphorescence of the probe molecule, the concentration of the dissolved oxygen can be quantitatively estimated. Thus, the dual-emissive materials, especially single dye molecules, should be feasible in various fields. ${ }^{7-11}$ However, there are still much room to explore the strategy for preparing the dual-emissive molecules. Especially, to apply the dual emission as a practical material in material science as well as in the biotechnology, the establishment of the molecular design for dual-emissive molecules with the bottom up strategy is essential. It is necessary to construct a dual-emissive dye based on the rational design.

A wide variety of elements including main group elements, transition metals and lanthanide ions are capable to form a complex with the $\beta$-diketonate ligand. ${ }^{12-15}$ The optical properties of the diketonates are varied by the types of the coordinated elements. In particular, organometallic diketonate complexes presented various useful characteristics in the polymeric materials according to the recent reports. For instance, it is known that the organoboron-containing compounds showed various unique optical properties. ${ }^{16-21}$ Boron diketonates and their derivatives are also work as emissive dyes with large molar absorption coefficients and high fluorescence quantum yields. $^{22-28}$ It has been demonstrated the modulation of optical properties by changing the complexation ratio of the diketonate ligands on the polymer main-chains. ${ }^{29}$ Boron diketonates work as a strong electron-acceptor. Significant emissions assigned as the intramolecular charge transfer (CT) states were obtained by increasing the introduction ratio of boron. In general, the CT state can be stabilized in the polar solvents, resulting in the red shift of the emission band. Based on this property, colorful emissive films were readily prepared from the single polymer structure only by changing the complexation ratio. It is known that the platinum complex with the diketonate ligand can show the strong phosphorescence. Swager et al. have reported that platinum diketonates with the expanded $\pi$-conjugation through the polymer main-chains showed the bright phosphorescence from a triplet $\pi-\pi^{*}$ ligand centered $\left({ }^{3} \mathrm{LC}\right)$ transition. ${ }^{30}$ These materials are applicable for improving the efficiencies of the recent opto and/or electric devices. ${ }^{31-39}$ According to these researches, it can be said that the organometallic diketonate ligands are versatile building blocks for constructing advanced optical materials. However, these organometallic diketonate complexes showed brilliant emissions and smart optical properties usually from the single type of metal element. There are very few studies to evaluate the electronic interaction and optical properties of the diketonate complexes with the heterogeneous metal elements in the single molecule. 
Scheme 1. Synthetic schemes of the diketonates compounds ${ }^{\mathrm{a}}$
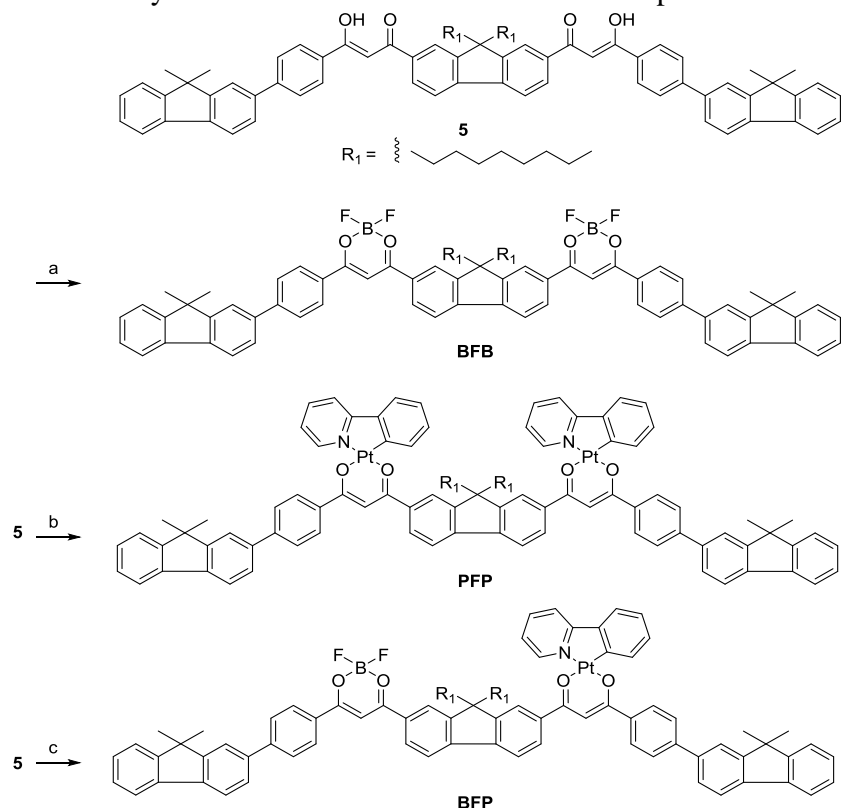

${ }^{a}$ Reagents and conditions: (a) $\mathrm{BF}_{3} \mathrm{OEt}_{2}$, dichloromethane, rt, $6 \mathrm{~h}$; (b) Pt dimer, $\mathrm{Na}_{2} \mathrm{CO}_{3}$, 2-ethoxyethanol, $100{ }^{\circ} \mathrm{C}, 24 \mathrm{~h}$; (c) i) Pt dimer, $\mathrm{Na}_{2} \mathrm{CO}_{3}, 2$

ethoxyethanol, $100{ }^{\circ} \mathrm{C}, 24 \mathrm{~h}$, ii) $\mathrm{BF}_{3} \cdot \mathrm{OEt}_{2}$, dichloromethane, r.t., $6 \mathrm{~h}$.

Herein, we report the synthesis and the dual-emission properties of the dye composed of heterogeneous organometallic compounds. Initially, the optical properties of the dual-core diads with two boron or platinum diketonates linked with the fluorene unit were investigated. The two boron complexes-containing diad provided fluorescence from the intramolecular CT band, and the platinum-containing one showed phosphorescence from ${ }^{3} \mathrm{LC}$ band. Next, to realize the simultaneous detection of each emission from the different spin multiplicities, the emission of the organometallic compound with boron and platinum diketonates linked with fluorene was evaluated. Accordingly, we obtained dual emission composed of fluorescence from the boron complex moiety and phosphorescence from the platinum complex moiety. The feasible strategy can be presented not only for designing dual-emissive compounds but also for obtaining the multi functions in the single molecule.

The synthetic outline of the complexes is shown in Scheme 1. Ligand $\mathbf{5}$ and boron diketonate BFB were prepared according to our previous work. ${ }^{29}$ To maintain the solubility of the diads, the 9 position at the center of the fluorene unit was modified with the alkyl chains. On the other hand, we found the steric hindrance of these alkyl chains crucially influenced on the yields in the palladium-catalyzed coupling reactions. When 2-ethylhexylsubstituted fluorene was used, the desired product was hardly obtained. Therefore, we used $n$-octyl groups in the diads. The formation of platinum diketonates was performed from $\mathbf{5}$ by the reaction with $\mathrm{Pt}$ dimer prepared with the Swager's report (Scheme S2). ${ }^{40}$ The boron platinum diketonate BFP was obtained via two steps from 5. The mono-substituted platinum complex was synthesized by treating with the 0.65 equivalent of $\mathrm{Pt}$ dimer. Subsequently, excess $\mathrm{BF}_{3} \cdot \mathrm{Et}_{2} \mathrm{O}$ solution was added to the monosubstituted complex. When boron complexation was carried out before the platinum introduction, a part of boron complexes were replaced to platinum complexes. The synthesized complexes were characterized by ${ }^{1} \mathrm{H},{ }^{13} \mathrm{C}$, and ${ }^{11} \mathrm{~B}$ NMR spectroscopies and mass measurements. Finally, we concluded that all products possessed the desired structures with enough purity for the optical measurements.
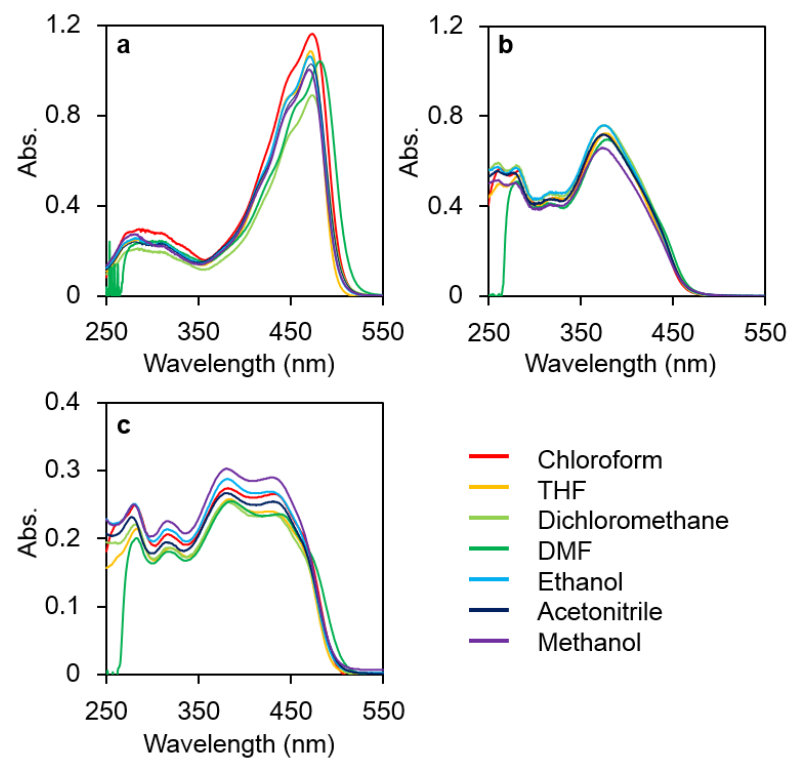

- Chloroform

- THF

- Dichloromethane

- DMF

- Ethanol

- Acetonitrile

- Methanol

Figure 1. UV-vis spectra of (a) BFB, (b) PFP and (c) BFP in seven types of organic solvents $\left(1.0 \times 10^{-5} \mathrm{M}\right)$.
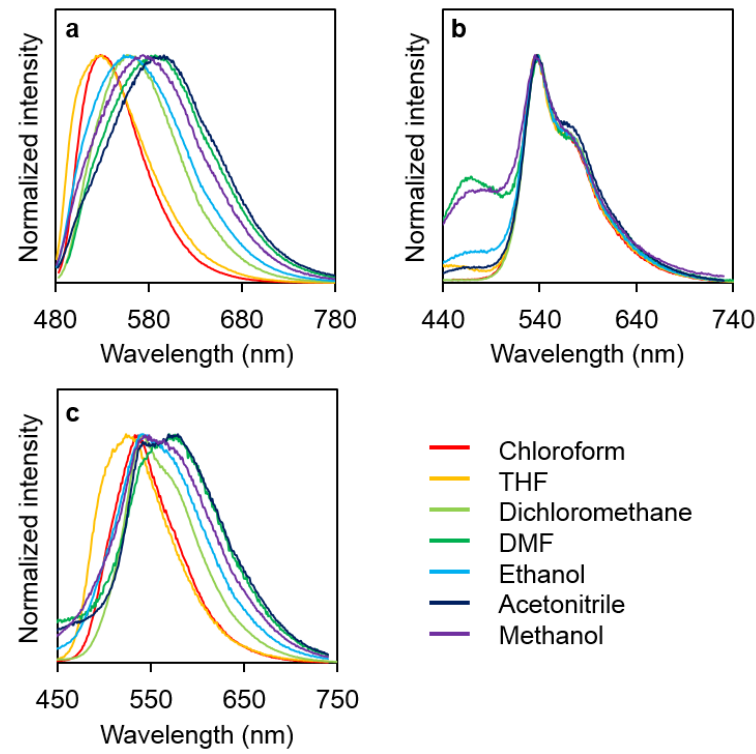

Figure 2. PL spectra of (a) BFB, (b) PFP and (c) BFP in seven organic solvents $\left(1.0 \times 10^{-5} \mathrm{M}\right)$ with the excitation light at the wavelength of the absorption maxima.

To investigate the electronic structures of the synthesized complexes at the ground state, UV-vis absorption spectra were monitored in seven organic solvents (Figure 1). The results are summarized in Table 1. The largest absorption bands with the peaks at $460 \mathrm{~nm}$ and $370 \mathrm{~nm}$ assigned to the $\pi-\pi^{*}$ transitions at each complex were observed from BFB and PFP in all organic solvents, respectively. BFP showed significant absorption bands with the peaks around $440 \mathrm{~nm}$ and $380 \mathrm{~nm}$. The shape of the spectrum of BFP can be explained simply by mixing BFB and PFP. These data suggest that the electronic interaction between boron and platinum diketonates could be small. In other words, the optical properties of each complex could be intrinsically preserved by the center fluorene unit. The solvent effects were slightly observed from the spectra. These data mean that the perturbation of the electronic structures by the solvent molecules such as coordination or protonation should hardly occur.

The electronic structures of the diketonates at the excited states were evaluated. Initially, the emission behavior of BFB 
Table 1. Photophysical properties of the diketonates in various kinds of solvents

\begin{tabular}{|c|c|c|c|c|c|c|c|c|c|}
\hline \multirow[b]{2}{*}{ Compound } & \multicolumn{3}{|c|}{ BFB } & \multicolumn{3}{|c|}{ PFP } & \multicolumn{3}{|c|}{ BFP } \\
\hline & $\Phi_{\mathrm{PL}}^{a}$ & $\begin{array}{c}\lambda_{\mathrm{Abs}, \max } \\
(\mathrm{nm})^{b}\end{array}$ & $\begin{array}{l}\lambda_{\mathrm{PL}, \max } \\
(\mathrm{nm})^{c}\end{array}$ & $\Phi_{\mathrm{PL}}^{a}$ & $\begin{array}{c}\lambda_{\mathrm{Abs}, \max } \\
(\mathrm{nm})^{b}\end{array}$ & $\begin{array}{l}\lambda_{\mathrm{PL}, \max } \\
(\mathrm{nm})^{c}\end{array}$ & $\Phi_{\mathrm{PL}}{ }^{a}$ & $\begin{array}{c}\lambda_{\mathrm{Abs}} \\
(\mathrm{nm})^{b}\end{array}$ & $\begin{array}{c}\lambda_{\mathrm{PL}} \\
(\mathrm{nm})^{c}\end{array}$ \\
\hline chloroform & 0.78 & 474 & 529 & 0.04 & 374 & 538 & 0.07 & 381,432 & 533 \\
\hline THF & 0.61 & 472 & 531 & 0.01 & 380 & 538 & 0.04 & 383,426 & 525 \\
\hline dichloromethane & 0.59 & 474 & 557 & 0.05 & 376 & 539 & 0.06 & 381,431 & 540 \\
\hline DMF & 0.01 & 483 & 588 & $<0.01$ & 380 & 539 & 0.01 & 385,437 & 573 \\
\hline ethanol & 0.10 & 471 & 560 & 0.01 & 377 & 538 & 0.02 & 381,428 & 541 \\
\hline acetonitrile & 0.01 & 473 & 597 & 0.01 & 373 & 537 & 0.01 & 380,430 & 541,579 \\
\hline methanol & 0.03 & 471 & 574 & $<0.01$ & 374 & 535 & 0.01 & 381,429 & 544 \\
\hline
\end{tabular}

${ }^{a}$ Absolute quantum yield.

${ }^{\mathrm{b}}$ Measured in the solution $\left(1.0 \times 10^{-5} \mathrm{M}\right)$.

${ }^{\mathrm{c}}$ Measured in the solution $\left(1.0 \times 10^{-5} \mathrm{M}\right)$ with the excitation light at the maximum peak wavelength of absorption.

Table 2. Stokes shift and life time of the diketonates in various kinds of solvents

\begin{tabular}{|c|c|c|c|c|c|}
\hline \multirow{2}{*}{ Compound } & \multicolumn{2}{|c|}{ BFB } & \multicolumn{2}{|c|}{ PFP } & \multirow{2}{*}{$\frac{\text { BFP }}{\tau(\mathrm{ns})^{a}}$} \\
\hline & Stokes shift $\left(\mathrm{cm}^{-1}\right)$ & $\tau(\mathrm{ns})^{a}$ & Stokes shift $\left(\mathrm{cm}^{-1}\right)$ & $\tau(\mathrm{ns})^{a}$ & \\
\hline chloroform & 2190 & 1.78 & 8150 & 426 & $1.96,308^{b}$ \\
\hline THF & 2350 & 1.70 & 7730 & $12.6(17 \%), 31.7(83 \%)$ & $\begin{array}{l}1.70(88 \%), 3.11(12 \%) \\
161(17 \%)^{b}, 353(83 \%)^{b}\end{array}$ \\
\hline dichloromethane & 3140 & 1.96 & 8040 & 508 & $\begin{array}{c}2.06 \\
190(23 \%)^{b}, 342(77 \%)^{b}\end{array}$ \\
\hline DMF & 3670 & $0.105(7 \%), 0.999(93 \%)$ & 7760 & $\begin{array}{c}0.434(5 \%) \\
2.60(21 \%), 6.89(74 \%)\end{array}$ & $\begin{array}{c}0.619(17 \%), 1.77(74 \%) \\
6.70(9 \%)\end{array}$ \\
\hline ethanol & 3370 & $0.315(20 \%), 1.08(80 \%)$ & 7940 & $14.8(22 \%), 35.5(78 \%)$ & $1.76(77 \%), 20.4(23 \%)$ \\
\hline acetonitrile & 4390 & $0.100(3 \%), 0.836(97 \%)$ & 8190 & $27.2(27 \%), 54.1(73 \%)$ & $0.144(56 \%), 29.8(44 \%)$ \\
\hline methanol & 3809 & $0.757(45 \%), 3.10(55 \%)$ & 8050 & $1.72(16 \%), 16.2(84 \%)$ & $0.967(83 \%), 10.7(17 \%)$ \\
\hline
\end{tabular}

${ }^{a}$ Measured in the solution, excited at $375 \mathrm{~nm}\left(1.0 \times 10^{-5} \mathrm{M}\right)$ and monitored at each emission maximum wavelength

${ }^{\mathrm{b}}$ Observed in the longer delay time regions.

was examined (Figure 2a). The PL spectra of BFB were measured in chloroform, THF, dichloromethane, DMF, ethanol, acetonitrile, and methanol with the excitation light at the peaks determined from absorption spectra (Table 2). As presented in the previous report, the optical property of BFB corresponded to the typical behavior as a CT emission. ${ }^{29}$ The bathochromic shift and the decreases of the emission intensity were observed by increasing solvent polarity. In chloroform, BFB showed strong emission with the peak at $529 \mathrm{~nm}$ with high emission efficiency (emission quantum yield, $\Phi=0.78$ ). In contrast, in acetonitrile, the emission band was observed in the red-shifted region with the peak at $597 \mathrm{~nm}$ with low efficiency $(\Phi=0.01)$. According to the Lippert-Mataga plots prepared from BFB, the linear relationship between the solvent polarity and the Stokes shifts was obtained (Figure 3a). The lifetime of BFB was about 1 3 ns in each solvent. These changes are the typical behavior as the fluorescence emission from the CT band.

The emission mechanism of PFP was investigated. PFP exhibited emission bands with the peaks around $540 \mathrm{~nm}$ in all organic solvents (Figures $2 b$ ). In particular, the significant peak shifts of the emission bands were less observed. Indeed, the less solvent effect was reflected in Lippert-Mataga plots (Figure 3b). The much longer lifetime (426 ns) was observed in chloroform comparing to that of BFB. This result indicates that the emission should be phosphorescence. In addition, the significant changes were observed from the PL spectra at $77 \mathrm{~K}$ in the glassy state (Figure 4). It is known that the metal-to-ligand CT-based transitions should be critically influenced from the solvent molecules because of large reorganization energies in the polar solvents or rigid media. ${ }^{41}$ These results indicate that the emission of PFP should be derived from the ${ }^{3} \mathrm{LC}$ transition. Similarly to the Swager's system, energy level of the ${ }^{3} \mathrm{LC}$ state could be lowered comparing to that of the ${ }^{3} \mathrm{CT}$ state by extending the conjugation of diketonate with the fluorene units, leading to the phosphorescence from the ${ }^{3} \mathrm{LC}$ transition. ${ }^{40}$

Finally, we evaluated the optical properties of BFP. Notably, the PL spectrum of BFP in acetonitrile exhibited two peaks at $541 \mathrm{~nm}$ and $579 \mathrm{~nm}$ (Figure 2). This result clearly indicates that
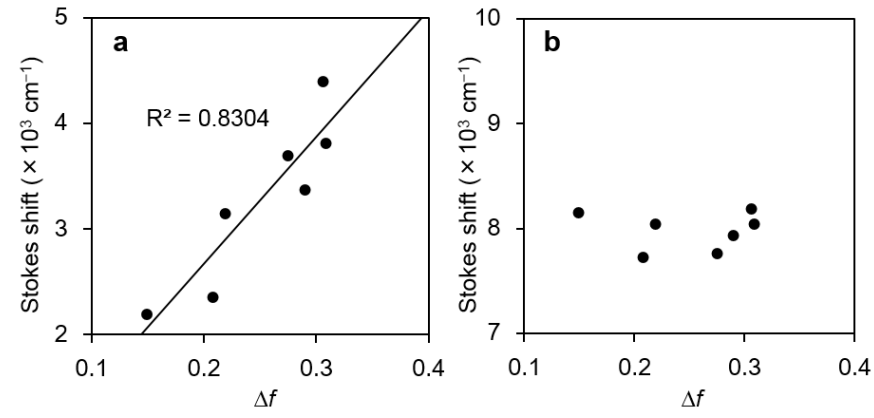

Figure 3. Lippert-Mataga plots of (a) BFB and (b) PFP. The protocols were shown in the Supporting Information.

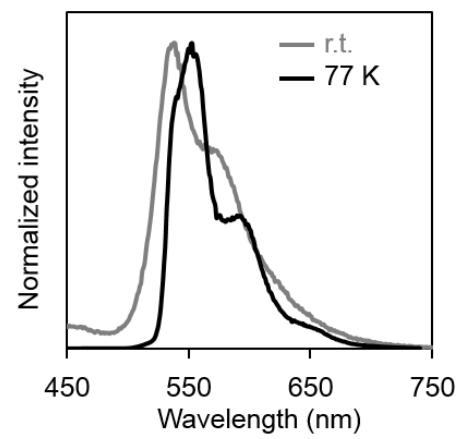

Figure 4. PL spectra of PFP in THF at room temperature (gray line) and in 2 -methyl THF at $77 \mathrm{~K}$ (black line).

BFP is the dual-emissive dye. To assign each emission band, we analyzed the optical properties. In contrast to PFP, the shape of the emission spectrum of BFP seemed to be affected by solvent polarity in the excited states. Although the two peaks were obtained in acetonitrile, the spectrum showed a single peak at $533 \mathrm{~nm}$ in chloroform. From the lifetime measurements, it is revealed that the emission of BFP mainly involves two elements with both of short (1.96 ns) attributable to the fluorescence and long life times (308 ns) attributed to the phosphorescence. The emissions of BFB and PFP in chloroform were located at near wavelength region, at $529 \mathrm{~nm}$ and $538 \mathrm{~nm}$, respectively. On the 


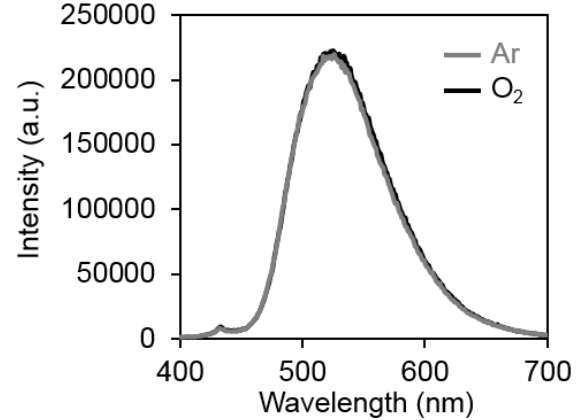

Figure 5. PL spectra of BFP in THF at room temperature after argon (gray line) or oxygen (black line) bubbling.

other hand, BFB and PFP showed the emission bands at $597 \mathrm{~nm}$ and $537 \mathrm{~nm}$ in acetonitrile, respectively. From these results, it can be summarized that BFP has dual emission properties composed of the fluorescence from boron diketonate and the phosphorescence from platinum diketonate. The emission of BFP is composed of the overlapping emissions of BFB and PFP. It should be notified that the phosphorescence emission of BFP was hardly influenced by the oxygen concentration (Figure 5). Even after oxygen bubbling through the solution, the magnitude of phosphorescence was maintained. Steric hindrance of alkyl chains at the center fluorene unit could contribute to the preservation of the emissions from both complexes.

We present the synthesis of the diketonate-based diads composed of heterogeneous organometallic complexes. The dual emissions were observed from the synthesized dyes by individually obtaining the emissions from each organometallic complex. This study involves two significant issues: The synthetic procedures for the tandem complexation with boron and platinum elements to the diketonate ligand were established. Because of a wide versatility of boron and platinum diketonates in the optical materials, useful information on the synthesis of the complexes can be provided. Secondly, we present the isolation effect of the fluorene unit in the middle of conjugation system, leading to the dual emissions with fluorescence and phosphorescence. Although the fluorescence quantum yields of boron diketonates were reduced by the introduction of platinum, the mixing spectra with the emissions generated from the different spin multiplicities were obtained. Our findings described here could be applicable for exploiting further combinations with different pairs of metal elements.

\section{Acknowledgments}

This work was partially supported by the JFE 21st Century Foundation (for K.T.), "the Adaptable and Seamless Technology Transfer Program" through target-driven R\&D, Japan Science and Technology Agency (JST) and a Grant-in-Aid for Scientific Research on Innovative Areas "New Polymeric Materials Based on Element-Blocks (No.2401)" (24102013) of The Ministry of Education, Culture, Sports, Science, and Technology, Japan.

\section{References and notes}

1. Wu, H.; Ying, L.; Yang, W.; Cao, Y. Chem. Soc. Rev. 2009, 38, 3391-3400.

2. Bu, J.; Watanabe, K.; Hayasaka, H.; Akagi, K. Nat. Commun. 2014, 5, DOI: $10.1038 /$ ncomms 4799.

3. Kajiwara, Y.; Nagai, A.; Tanaka, K.; Chujo, Y. J. Mater. Chem. C 2013, 1, 4437-4444.

4. Okamoto, A.; Tainaka, K.; Nishiza, K.; Saito, I. J. Am. Chem. Soc. 2005, 127, 13128-13129.

5. Palmer, G. M.; Fontanella, A. N.; Zhang, G.; Hanna, G.; Fraser, C. L.; Dewhirst, M. W. J. Biomed. Opt. 2010, 15, 066021.
6. Zhang, G.; Palmer, G. M.; Dewhirst, M. W.; Fraser, C. L. Nat. Mater. 2009, 8, 747-751.

7. Morimoto, T.; Ito, M.; Koike, K.; Kojima, T.; Ozeki, T.; Ishitani, O. Chem. Eur. J. 2012, 18, 3292-3304.

8. Hudson, Z. M.; Zhao, S.-B.; Wang, R.-Y.; Wang, S. Chem. Eur. J. 2009, 15, 6131-6137.

9. Liu, Y.; Guo, H.; Zhao, J. Chem. Commun., 2011, 47, 11471-11473.

10. Suzuki, T.; Kuchiyama, T.; Kishi, S.; Kaizaki, S.; Takagi, H. D.; Kato, M. Inorg. Chem. 2003, 42, 785-795.

11. Inoue, Y.; Jiang, P.; Tsukada, E.; Wada, T.; Shimizu, H.; Tai, A.; Ishikawa, M. J. Am. Chem. Soc. 2002, 124, 6942-6949.

12. Otway, D. J.; Rees, W. S., Jr. Coord. Chem. Rev. 2000, 210, 279-328.

13. Marciniak, B.; Buono-Core, G. E. J. Photochem. Photobiol., A 1990, 52, 1-25.

14. Liu, S.-J.; Chen, Y.; Xu, W.-J.; Zhao, Q.; Huang, W. Macromol. Rapid Commun. 2012, 33, 461-480.

15. Binnemans, K. Handbook on the Physics and Chemistry of Rare Earths 2005, 35, pp. 107-272.

16. Tanaka, K.; Chujo, Y. Macromol. Rapid Commun. 2012, 33, 1235-1255.

17. Yoshii, R.; Nagai, A.; Tanaka, K.; Chujo, Y. J. Polym. Sci. Part A: Polym. Chem. 2013, 51, 1726-1733.

18. Tanaka, K.; Yamane, H.; Yoshii, R.; Chujo, Y. Bioorg. Med. Chem. 2013, 21, 2715-2719.

19. Yeo, H.; Tanaka, K.; Chujo, Y. Macromolecules 2013, 46, 2599_ 2605.

20. Yoshii, R.; Yamane, H.; Nagai, A.; Tanaka, K.; Taka, H.; Kita, H.; Chujo, Y. Macromolecules 2014, 47, 2316-2323.

21. Yoshii, R.; Yamane, H.; Tanaka, K.; Chujo, Y. Macromolecules 2014, 47, 3755-3760.

22. Maeda, H.; Mihashi, Y.; Haketa, Y. Org. Lett. 2008, 10, 3179-3182.

23. Ono, K.; Yoshikawa, K.; Tsuji, Y.; Yamaguchi, H.; Uozumi, R.; Tomura, M.; Taga, K.; Saito, K. Tetrahedron 2007, 63, 9354-9358.

24. Zhang, G.; Chen, J.; Payne, S. J.; Kooi, S. E.; Demas, J. N.; Fraser, C. L. J. Am. Chem. Soc. 2007, 129, 8942-8943.

25. Yoshii, R.; Nagai, A.; Tanaka, K.; Chujo, Y. Chem. Eur. J. 2013, 19, 4506-4512.

26. Yoshii, R.; Tanaka, K.; Chujo, Y. Macromolecules 2014, 47, 2268-2278.

27. Yoshii, R.; Nagai, A.; Tanaka, K.; Chujo, Y. Macromol. Rapid Commun. 2014, 35, 1315-1319.

28. Yoshii, R.; Hirose, A.; Tanaka, K.; Chujo, Y. Chem. Eur. J. 2014, 20, 8320-8324.

29. Tanaka, K.; Tamashima, K.; Nagai, A.; Okawa, T.; Chujo, Y. Macromolecules 2013, 46, 2969-2975.

30. Thomas, S. W., III.; Yagi, S.; Swager, T. M. J. Mater. Chem. 2005 15, 2829-2835.

31. Nagai, A.; Kokado, K.; Nagata, Y.; Chujo, Y. Macromolecules 2008, 41, 8295-8298.

32. Cogné-Laage, E.; Allemand, J.-F.; Ruel, O.; Baudin, J.-B.; Croquette, V.; Blanchard-Desce, M.; Jullien, L. Chem. Eur. J. 2004, 10, 1445-1455.

33. Wong, W.-Y.; Wang, X.-Z.; He, Z.; Djurišić, A. B.; Yip, C.-T.; Cheung, K.-Y.; Wang, H.; Mak, C. S. K.; Chan, W.-K. Nat. Mater. 2007, 6, 521-527.

34. Zhang, W.; Fang, Z.; Su, M.; Saeys, M.; Liu, B. Macromol. Rapid Commun. 2009, 30, 1533-1537.

35. Wang, Q.; Wong, W.-Y. Polym. Chem. 2011, 2, 432-440.

36. D'Andrade, B. W.; Thompson, M. E.; Forrest, S. R. Adv. Mater. 2002, 14, 147-151.

37. Adamovich, V.; Brooks, J.; Tamayo, A.; Alexander, A. M.; Djurovich, P., I.; D’Andrade, B.; Adachi, C.; Forrest, S. R.; Thompson, M. E. New J. Chem. 2002, 26, 1171-1178.

38. Shigehiro, T.; Yagi, S.; Maeda, T.; Nakazumi, H.; Fujiwara, H.; Sakurai, Y. J. Phys. Chem. C 2013, 117, 532-542.

39. Furuta, P. T.; Deng, L.; Garon, S.; Thompson, M. E.; Fréchet, J. M. J. J. Am. Chem. Soc. 2004, 126, 15388-15389.

40. Godbert, N.; Pugliese, T.; Aiello, I.; Bellusci, A.; Crispini, A.; Ghedini, M. Eur. J. Inorg. Chem. 2007, 5105-5111.

41. Glusac, K. D.; Jiang, S.; Schanze, K. S. Chem. Commun. 2002 , 2504-2505. 
Supporting Information

Synthesis of Dual-Emissive Organometallic Complexes Containing Heterogeneous Metal Elements

Amane Hirose, Kazuo Tanaka*, Kenji Tamashima, Yoshiki Chujo*

Department of Polymer Chemistry, Graduate School of Engineering, Kyoto University, Katsura, Nishikyo-ku, Kyoto 615-8510, Japan

Phone: +81-75-383-2604

Fax: +81-75-383-2605

*To whom correspondence should be addressed: chujo@chujo.synchem.kyoto-u.ac.jp 


\section{Experimental.}

General. ${ }^{11} \mathrm{H}(400 \mathrm{MHz}),{ }^{13} \mathrm{C}(100 \mathrm{MHz})$, and ${ }^{11} \mathrm{~B}(128 \mathrm{MHz})$ NMR spectra were recorded on JEOL JNM-EX400 spectrometers. In ${ }^{1} \mathrm{H}$ NMR spectra and ${ }^{13} \mathrm{C}$ NMR spectra, tetramethylsilane (TMS) was used as an internal standard in $\mathrm{CDCl}_{3}$ and $\mathrm{CD}_{2} \mathrm{Cl}_{2}$. In ${ }^{11} \mathrm{~B}$ NMR spectra, $\mathrm{BF}_{3} \cdot \mathrm{OEt}_{2}$ (sealed capillary) was used as an external standard. Recyclable preparative high-performance liquid chromatography (HPLC) was carried out on a Japan Analytical Industry Model LC918R (JAIGEL-1H and 2H columns) using chloroform as an eluent. UV-vis absorption spectra were recorded on a Shimadzu UV-3600 spectrophotometer (Shimadzu Corp., Kyoto, Japan). Emission spectra were recorded on a HORIBA JOBIN YVON Fluoromax-4 spectrofluorometer, and absolute quantum yields were determined by the integrating sphere method on the HORIBA JOBIN YVON Fluoromax-4 spectrofluorometer in chloroform (HORIBA, Ltd., Kyoto, Japan). Photoluminescence (PL) lifetime was measured by a Horiba FluoreCube spectrofluorometer system and excitation was carried out at $375 \mathrm{~nm}$ using UV diode laser (NanoLED $375 \mathrm{~nm}$ ).

Materials. 2,7-Dibromo-9,9-di-n-octylfluorene, $\mathrm{Boc}_{2} \mathrm{O}$ (di-tert-butyl dicarbonate), DMAP (4-dimethylaminopyridine), $\mathrm{Pd}_{2}(\mathrm{dba})_{3}(\mathrm{dba}=$ dibenzylideneacetone $)$ and piperidine were purchased 
from Tokyo Chemical Industry CO.,LTD. (Tokyo, Japan). 4'-Iodoacetophenone, NaH (sodium hydride) in mineral oil (50 72\%), (9,9-dimethyl-fluoren-2-yl)boronic acid, S-Phos (2-dicyclohexylphosphino-2',6'-dimethoxybiphenyl), $\mathrm{Cs}_{2} \mathrm{CO}_{3}$, 2-phenylpyridine, $\mathrm{K}_{2}\left[\mathrm{PtCl}_{4}\right]$ and $\mathrm{Na}_{2} \mathrm{CO}_{3}$ were purchased from Wako Pure Chemical Industries Ltd. (Osaka, Japan). $n$-BuLi in $n$-hexane $(1.6 \mathrm{~mol} / \mathrm{L})$ was purchased from Kanto Chemical, CO.,INC. (Tokyo, Japan). All solvents were used as a deoxidized grade. All chemicals and solvents were used as received without further purification. The syntheses of the complexes were outlined in Schemes 1 and S1. The diketonate ligand $\mathbf{5}$ and boron diketonate BFB were synthesized according to our previous work (ref \#29 in the main text). The synthesis of the ligand was carried out according to Schemes S1 and S2.

Synthesis of 2. Dicarboxylic acid 1 was prepared according to the previous report (Chujo et al. Macromolecules 2013, 46, 2969). The mixture containing 1 (9.2 g, $19.2 \mathrm{mmol})$ and conc. $\mathrm{H}_{2} \mathrm{SO}_{4}(96 \%, 2 \mathrm{~mL})$ in methanol $(180 \mathrm{~mL})$ was refluxed for $16 \mathrm{~h}$. After neutralization with sat. $\mathrm{NaHCO}_{3} a q$. and evaporation, the residue was dissolved in cyclopentyl methyl ether (CPME), and the organic layer was washed with water, sat. $\mathrm{NaHCO}_{3}$ aq. and brine. After drying over $\mathrm{Na}_{2} \mathrm{SO}_{4}$, volatiles were removed by evaporation. The product 2 was obtained as a white solid $(8.9 \mathrm{~g}, 91 \%)$. The authentic sample was purified with recrystallization with THF and methanol. ${ }^{1} \mathrm{H} \mathrm{NMR}\left(\mathrm{CD}_{2} \mathrm{Cl}_{2}\right.$, ppm) $\delta 8.07(\mathrm{~d}, J=1.44 \mathrm{~Hz}, 2 \mathrm{H}), 8.06(\mathrm{~d}, J=1.96 \mathrm{~Hz}, 2 \mathrm{H}), 7.83(\mathrm{~d}, J=8.56,2 \mathrm{H}), 3.93$ (s, 6H), 2.12-2.05 (m, 4H), 1.25-0.95 (m, 20H), $0.80(\mathrm{t}, J=7.20 \mathrm{~Hz}, 6 \mathrm{H}), 0.58-0.49(\mathrm{~m}$, $4 \mathrm{H}) .{ }^{13} \mathrm{C}$ NMR $\left(\mathrm{CD}_{2} \mathrm{Cl}_{2}, \mathrm{ppm}\right) \delta 167.48,152.30,144.89,130.29,129.17,124.55,120.73$, 55.97, 52.41, 40.40, 32.16, 30.25, 29.58, 29.53, 24.13, 22.98, 14.21. HRMS (ESI): calcd for $\left[\mathrm{C}_{33} \mathrm{H}_{46} \mathrm{O}_{4}+\mathrm{H}\right]^{+}: \mathrm{m} / \mathrm{z}$ 507.3469; found: $\mathrm{m} / \mathrm{z} 507.3475$ 
Synthesis of 3. In a round bottom flask with a drop funnel, $2(3.0 \mathrm{~g}, 5.9 \mathrm{mmol})$ and $\mathrm{NaH}$ (1.4 mg, $59.3 \mathrm{mmol}$ ) were placed under nitrogen atmosphere. The THF solution (50 $\mathrm{mL})$ containing $p$-iodoacetophenone $(3.8 \mathrm{mg}, 15.4 \mathrm{mmol})$ was added dropwise at $50{ }^{\circ} \mathrm{C}$ over $30 \mathrm{~min}$, and the solution color gradually turned from yellow to orange. Then, the mixture was stirred at $50{ }^{\circ} \mathrm{C}$ for $16 \mathrm{~h}$. After quenching the reaction by adding conc. $\mathrm{HCl}$ (10\%) and removing volatiles by evaporation, the residue was dissolved in CPME, and the organic layer was washed with water, sat. $\mathrm{NaHCO}_{3} a q$. and brine. After drying over $\mathrm{Na}_{2} \mathrm{SO}_{4}$, volatiles were removed by evaporation. The crude product was purified by the silica gel column chromatography with a mixed eluent containing toluene / $n$-hexane (1/4). Recrystallization with THF and hexane afforded $\mathbf{3}(1.8 \mathrm{~g}, 32 \%)$ as a yellow solid. ${ }^{1} \mathrm{H}$ NMR $\left(\mathrm{CD}_{2} \mathrm{Cl}_{2}, \mathrm{ppm}\right) \delta 17.05(\mathrm{~s}, 2 \mathrm{H}), 8.05(\mathrm{~d}, J=6.84 \mathrm{~Hz}, 4 \mathrm{H}), 7.91-7.88(\mathrm{~m}, 6 \mathrm{H})$, $7.76(\mathrm{~d}, J=4.8 \mathrm{~Hz}, 4 \mathrm{H}), 6.95(\mathrm{~s}, 2 \mathrm{H}), 2.16-2.12(\mathrm{~m}, 4 \mathrm{H}), 1.20-1.00(\mathrm{~m}, 20 \mathrm{H}), 0.77(\mathrm{t}, J$ $=7.08 \mathrm{~Hz}, 6 \mathrm{H}), 0.65-0.55(\mathrm{~m}, 4 \mathrm{H}) .{ }^{13} \mathrm{C} \mathrm{NMR}\left(\mathrm{CD}_{2} \mathrm{Cl}_{2}, \mathrm{ppm}\right) \delta 186.48,184.85,152.77$, $144.92,138.44,135.51,135.46,129.00,127.17,122.18,121.13,100.13,93.55,56.21$, $40.45,32.17,30.26,29.61,29.56,24.21,22.99$, 14.22. HRMS (ESI): calcd for $\left[\mathrm{C}_{47} \mathrm{H}_{52} \mathrm{I}_{2} \mathrm{O}_{4}+\mathrm{H}\right]^{+}: \mathrm{m} / \mathrm{z}$ 935.2028; found: $\mathrm{m} / \mathrm{z}$ 935.2034.

Synthesis of 4. The mixture of $\mathbf{3}$ (1.5 g, $1.6 \mathrm{mmol})$, 4,4-dimethylaminopyridine ( $0.2 \mathrm{~g}$, $1.6 \mathrm{mmol})$, and di-t-butyl dicarbonate $\left(\mathrm{Boc}_{2} \mathrm{O}, 3.5 \mathrm{~g}, 16 \mathrm{mmol}\right)$ in 1,4-dioxane $(150 \mathrm{~mL})$ was stirred at $40{ }^{\circ} \mathrm{C}$ for $24 \mathrm{~h}$. After cooling to room temperature, the reaction solution was directly passed through the silica gel swollen with chloroform. After washing with chloroform and subsequently removing solvents, 4 was obtained $(1.2 \mathrm{~g}, 64 \%)$ as a yellow solid. ${ }^{1} \mathrm{H}$ NMR $\left(\mathrm{CD}_{2} \mathrm{Cl}_{2}, \mathrm{ppm}\right) \delta$ 8.02-7.98 (m, 2H), 7.90-7.86 (m, 4H), 7.84 (d, $J=8.4 \mathrm{~Hz}, 2 \mathrm{H}), 7.80-7.79(\mathrm{~m}, 4 \mathrm{H}), 7.49(\mathrm{~d}, J=8.32 \mathrm{~Hz}, 2 \mathrm{H}), 7.26(\mathrm{~s}, 1 \mathrm{H}), 7.19(\mathrm{~s}, 1 \mathrm{H})$, 
$2.15-2.05(\mathrm{~m}, 4 \mathrm{H}), 1.53(\mathrm{~s}, 18 \mathrm{H}), 1.25-1.00(\mathrm{~m}, 20), 0.78(\mathrm{t}, J=7.36 \mathrm{~Hz}), 0.65-0.50$ $(\mathrm{m}, 4 \mathrm{H}) .{ }^{13} \mathrm{C}$ NMR $\left(\mathrm{CD}_{2} \mathrm{Cl}_{2}, \mathrm{ppm}\right) \delta 188.11,188.08,187.84,187.83,157.75,157.70$, 155.98. 155.93, 153.05, 152.79, 152.57, 152.32, 150.01, 150.01, 149.93, 144.96, 144.85, $143.58,143.46,138.53,138.51,138.44,138.41,183.33,138.26,134.04,134.03,134.00$, $133.76,129.92,128.28,128.22,127.94,126.02,125.99,123.03,123.01,121.47,121.17$, $120.98,120.82,120.67,110.70,110.67,109.43,109.30,100.80,100.78,97.87,97.85$, $84.523,84.516,84.46,84.45,56.10,56.05,56.00,40.44,32.10,30.29,30.27,30.25$, 29.62, 29.58, 29.56, 29.55, 27.74, 27.72, 24.21, 22.92, 15.43, 14.18. HRMS (ESI): calcd for $\left[\mathrm{C}_{57} \mathrm{H}_{68} \mathrm{I}_{2} \mathrm{O}_{8}+\mathrm{Na}\right]^{+}: \mathrm{m} / \mathrm{z}$ 1157.2896; found: $\mathrm{m} / \mathrm{z} 1157.2919$.

Synthesis of 5. The mixture containing $4 \quad(650 \quad \mathrm{mg}, \quad 0.57 \quad \mathrm{mmol})$, 9,9-dimethyl-9H-fluorene-2-yl-boronic acid (327 $\mathrm{mg}, 1.37 \mathrm{mmol})$, 2-dicyclohexylphosphino-2',6'-dimethoxybiphenyl (S-Phos, $9.4 \mathrm{mg}, 0.02 \mathrm{mmol}$ ), tris(dibenzylideneacetone)dipalladium(0) $\left(\mathrm{Pd}_{2}(\mathrm{dba})_{3}, 5.2 \mathrm{mg}, 6 \mu \mathrm{mol}\right)$, and $\mathrm{Cs}_{2} \mathrm{CO}_{3}$ $(1.87 \mathrm{~g}, 5.73 \mathrm{mmol})$ in toluene $(12 \mathrm{~mL})$ and water $(12 \mathrm{~mL})$ was stirred at $80{ }^{\circ} \mathrm{C}$ for $16 \mathrm{~h}$. After reaction, an excess amount of cyclopentyl methyl ether was poured to the mixture, and the organic layer was washed with water, sat. $\mathrm{NaHCO}_{3} a q$. and brine. After drying over $\mathrm{Na}_{2} \mathrm{SO}_{4}$, volatiles were removed by evaporation. To the solution of the residue in dichloromethane $(80 \mathrm{~mL})$, piperidine $(113 \mu \mathrm{L}, 1.15 \mathrm{mmol})$ was added, and then the mixture was stirred at room temperature for $16 \mathrm{~h}$. After neutralization with conc. $\mathrm{HCl}$ $(10 \%)$, the products in dichloromethane were washed with water, sat. $\mathrm{NaHCO}_{3} a q$. and brine. After removing volatiles by evaporation, the crude products were purified with the silica gel column chromatography with a mixed eluent containing $n$-hexane / toluene (1/1). Recrystallization with THF and hexane gave 5 (379 $\mathrm{mg})$ as a yellow solid in $62 \%$ 
yield. ${ }^{1} \mathrm{H}$ NMR $\left(\mathrm{CD}_{2} \mathrm{Cl}_{2}\right.$, ppm) $\delta 17.17(\mathrm{~s}, 2 \mathrm{H}), 8.14(\mathrm{~d}, J=8.30 \mathrm{~Hz}, 4 \mathrm{H}), 8.10-8.05(\mathrm{~m}$, 4H), $7.90(\mathrm{~d}, J=8.32 \mathrm{~Hz}, 2 \mathrm{H}), 7.84-7.80(\mathrm{~m}, 6 \mathrm{H}), 7.78-7.71(\mathrm{~m}, 4 \mathrm{H}), 7.66\left(\mathrm{dd}, J_{1}=\right.$ 7.84, $\left.J_{2}=1.96 \mathrm{~Hz}, 2 \mathrm{H}\right), 7.48-7.45(\mathrm{~m}, 2 \mathrm{H}), 7.37-7.31(\mathrm{~m}, 4 \mathrm{H}), 7.04(\mathrm{~s}, 2 \mathrm{H}), 2.18-2.10$ $(\mathrm{m}, 4 \mathrm{H}), 1.52(\mathrm{~s}, 12 \mathrm{H}), 1.21-0.96(\mathrm{~m}, 20 \mathrm{H}), 0.76(\mathrm{t}, J=6.88 \mathrm{~Hz}, 6 \mathrm{H}), 0.62-0.54(\mathrm{~m}$, $4 \mathrm{H}) .{ }^{13} \mathrm{C} \mathrm{NMR}\left(\mathrm{CD}_{2} \mathrm{Cl}_{2}, \mathrm{ppm}\right) \delta 186.23,185.48,155.01,154.54,152.79,146.03,144.85$, $139.89,139.34,138.97,135.80,134.57,128.18,128.06,127.70,127.55,127.14,126.73$, $123.14,122.20,121.92,121.09,120.87,120.65,93.70,56.26,47.44,40.53,32.20$, 30.30, 29.65, 29.60, 27.41, 24.27, 23.02, 14.23. HRMS (ESI): calcd for $\left[\mathrm{C}_{77} \mathrm{H}_{79} \mathrm{O}_{4}+\mathrm{H}\right]^{+}$: m/z 1067.5973; found: m/z 1067.5987.

Synthesis of BFB. The mixture containing $5(100 \mathrm{mg}, 0.09 \mathrm{mmol})$ and $\mathrm{BF}_{3} \cdot \mathrm{Et}_{2} \mathrm{O}(60$ $\mu \mathrm{L}, 0.45 \mathrm{mmol})$ in dichloromethane $(20 \mathrm{~mL})$ was stirred at room temperature for $6 \mathrm{~h}$. After quenching the reaction by diluting with dichloromethane, the organic layer was washed with water, sat. $\mathrm{NaHCO}_{3} a q$. and brine. After drying over $\mathrm{Na}_{2} \mathrm{SO}_{4}$, the products were suspended onto silica gel. The crude product was purified by the silica gel column chromatography with a mixed eluent containing $n$-hexane / toluene (1/2). The pure BFB was obtained (41 mg, 75\%) as an orange solid. ${ }^{1} \mathrm{H} \mathrm{NMR}\left(\mathrm{CD}_{2} \mathrm{Cl}_{2}, \mathrm{ppm}\right) \delta 8.50-8.42(\mathrm{~m}$, $8 \mathrm{H}), 8.19(\mathrm{~d}, J=8.28 \mathrm{~Hz}, 2 \mathrm{H}), 8.02(\mathrm{~d}, J=8.28 \mathrm{~Hz}, 4 \mathrm{H}), 7.95-7.89(4 \mathrm{H}, \mathrm{m}), 7.84-7.78$ $(6 \mathrm{H}, \mathrm{m}), 7.54-7.50(2 \mathrm{H}, \mathrm{m}), 7.38-7.31(4 \mathrm{H}, \mathrm{m}), 2.35-2.28(4 \mathrm{H}, \mathrm{m}), 1.58(\mathrm{~s}, 12 \mathrm{H})$, 1.25-1.00 (m, 20H), $0.80(\mathrm{t}, J=7.32 \mathrm{~Hz}, 6 \mathrm{H}), 0.70-0.58(\mathrm{~m}, 4 \mathrm{H}) .{ }^{13} \mathrm{C}$ NMR $\left(\mathrm{C}_{4} \mathrm{D}_{8} \mathrm{O}\right.$, ppm) $\delta 183.37,183.34,155.57,155.10,154.05,149.16,147.34,141.17,139.42,139.23$, $133.94,132.01,130.55,129.91,128.61,128.35,127.95,127.43,124.35,123.47,122.56$, $122.43,121.34,121.16,94.77,57.19,47.82,40.51,32.70,30.84,30.15,30.13,27.40$, 24.80, 23.42, 14.32. ${ }^{11} \mathrm{~B}$ NMR $\left(\mathrm{CD}_{2} \mathrm{Cl}_{2}, \mathrm{ppm}\right) \delta$ 0.20. HRMS (ESI): calcd for 
$\mathrm{C}_{77} \mathrm{H}_{76} \mathrm{~B}_{2} \mathrm{~F}_{4} \mathrm{O}_{4}: \mathrm{m} / \mathrm{z}$ 1162.5894; found: m/z 1162.5901.

Synthesis of Pt dimer. The Pt dimer was synthesized according to Ghedini's report (ref. \#40, Scheme S2). In a round-bottom flask, 2-phenylpyridine (1.4 g, $9.3 \mathrm{mmol})$ was placed under a nitrogen atmosphere, and 2-ethoxyethanol $(50 \mathrm{~mL})$ was added. A solution of $\mathrm{K}_{2}\left[\mathrm{PtCl}_{4}\right](4.3 \mathrm{~g}, 10.4 \mathrm{mmol})$ in degassed water $(100 \mathrm{~mL})$ was added dropwise at $80{ }^{\circ} \mathrm{C}$, and then, the mixture was stirred for $6 \mathrm{~h}$. The precipitate was collected by filtration and washed with methanol and water. Pt dimer was obtained $(3.06 \mathrm{~g}, 77 \%)$ as a black-green solid. The product was used for the next step directly.

Synthesis of PFP. In a round-bottom flask, 5 (130 mg, $0.122 \mathrm{mmol})$, Pt dimer (187 mg, $0.244 \mathrm{mmol})$ and $\mathrm{Na}_{2} \mathrm{CO}_{3}(130 \mathrm{mg}, 1.23 \mathrm{mmol})$ were placed under a nitrogen atmosphere, and 2-ethoxyethanol $(80 \mathrm{~mL})$ was added. The mixture was stirred at $100{ }^{\circ} \mathrm{C}$ for $24 \mathrm{~h}$. After cooling to room temperature, the product was extracted with $\mathrm{CH}_{2} \mathrm{Cl}_{2}$ and washed by water. The organic layer was dried over magnesium sulfate and concentrated by a rotary evaporator. The crude product was suspended onto silica gel and purified by the silica gel column chromatography with a mixed eluent containing $n$-hexane/AcOEt (6:1). The desired compound was separated with HPLC in chloroform and precipitated in $n$-hexane. The pure PFP was obtained $(110 \mathrm{mg}, 51 \%)$ as a gray solid. ${ }^{1} \mathrm{H}$ NMR 
$\left(\mathrm{CD}_{2} \mathrm{Cl}_{2}, \mathrm{ppm}\right) \delta 9.20-9.18(2 \mathrm{H}, \mathrm{m}), 8.28-8.14(8 \mathrm{H}, \mathrm{m}), 7.94-7.78(17 \mathrm{H}, \mathrm{m}), 7.71-7.69$ $(4 \mathrm{H}, \mathrm{m}), 7.54-7.49(4 \mathrm{H}, \mathrm{m}), 7.38(4 \mathrm{H}, \mathrm{dd}, J=8.8,5.4 \mathrm{~Hz}), 7.31-7.29(2 \mathrm{H}, \mathrm{m})$, $7.23-7.18(4 \mathrm{H}, \mathrm{m}), 6.97(2 \mathrm{H}, \mathrm{d}, J=2.0 \mathrm{~Hz}), 2.24-2.23(4 \mathrm{H}, \mathrm{m}), 1.54(12 \mathrm{H}, \mathrm{s})$, 1.19-1.15 (20H, m), 0.80 (4H, br s), $0.77(6 \mathrm{H}, \mathrm{t}, J=6.6 \mathrm{~Hz}) .{ }^{13} \mathrm{C} \mathrm{NMR}\left(\mathrm{CD}_{2} \mathrm{Cl}_{2}, \mathrm{ppm}\right)$ $\delta 179.52,179.48,178.68,178.67,178.66,178.44,178.39,177.56,177.54,168.04$, $167.99,154.21,153.73,151.85,151.83,151.82,151.79,146.99,146.87,144.75$, $144.73,143.73,143.72,143.53,143.07,142.97,142.84,142.74,139.45,139.36$, $139.06,139.04,139.03,139.01,138.85,138.80,138.70,138.61,138.36,138.34$, $138.14,137.51,130.53,130.50,128.89,127.35,127.23,127.20,126.98,126.94$, $126.81,126.34,126.32,126.13,125.90,125.88,125.88,123.38,123.36,122.88$, $122.40,121.70,121.37,121.26,121.04,120.22,120.17,120.11,120.08,119.89$, $118.40,118.37,97.13,55.32,46.79,40.16,40.11,31.62,30.05,30.02,29.98,29.17$, 26.86, 23.98, 22.45, 13.69. HRMS (APCI): calcd for $\left[\mathrm{C}_{99} \mathrm{H}_{92} \mathrm{~N}_{2} \mathrm{O}_{4} \mathrm{Pt}_{2}+\mathrm{H}\right]^{+}: \mathrm{m} / \mathrm{z}$ 1762.6404; found: $\mathrm{m} / \mathrm{z} 1762.6414$.

Synthesis of BFP. In a round-bottom flask, 5 (70 mg, $0.066 \mathrm{mmol})$, Pt dimer (31 mg, $0.040 \mathrm{mmol})$ and $\mathrm{Na}_{2} \mathrm{CO}_{3}(70 \mathrm{mg}, 0.66 \mathrm{mmol})$ were placed under a nitrogen atmosphere, and 2-ethoxyethanol $(20 \mathrm{~mL})$ was added. The mixture was stirred at $100{ }^{\circ} \mathrm{C}$ for $24 \mathrm{~h}$. 
After cooling to room temperature, the product was extracted with $\mathrm{CH}_{2} \mathrm{Cl}_{2}$ and washed by water. The organic layer was dried over magnesium sulfate and concentrated by a rotary evaporator. The crude product was suspended onto silica gel and purified by the silica gel column chromatography with a mixed eluent containing $n$-hexane/chloroform (1:2). The crude mono Pt complex was obtained (36 mg). $\mathrm{BF}_{3} \cdot \mathrm{Et}_{2} \mathrm{O}(6.4 \mu \mathrm{L}, 0.050$ mmol) was added to the mixture of the product in dichloromethane $(20 \mathrm{~mL})$ at room temperature under a nitrogen atmosphere. After $6 \mathrm{~h}$, the product was extracted with $\mathrm{CH}_{2} \mathrm{Cl}_{2}$ and washed by water. The organic layer was dried over magnesium sulfate and concentrated by a rotary evaporator. The crude product was separated with HPLC in chloroform and precipitated in $n$-hexane. The pure BFP was obtained (18 $\mathrm{mg}, 19 \%)$ as a gray solid. ${ }^{1} \mathrm{H}$ NMR $\left(\mathrm{CD}_{2} \mathrm{Cl}_{2}\right) \delta 9.13(1 \mathrm{H}, \mathrm{br} \mathrm{s}), 8.24-8.07(8 \mathrm{H}, \mathrm{m}), 7.85-7.69(18 \mathrm{H}, \mathrm{m})$, 7.46-7.43 (3H, m), 7.30-7.28 (4H, m), 7.23-7.16 (2H, m), 7.09-7.07 (1H, m), 6.90-6.88 (1H, m), 2.15-2.13 (4H, m), $1.48(12 \mathrm{H}, \mathrm{s}), 1.06(20 \mathrm{H}, \mathrm{s}), 0.69(10 \mathrm{H}, \mathrm{s}) .{ }^{13} \mathrm{C}$ $\mathrm{NMR}\left(\mathrm{CD}_{2} \mathrm{Cl}_{2}, \mathrm{ppm}\right) \delta 181.64,181.31,180.83,180.76,178.99,178.50,178.36,178.16$, $177.91,177.85,177.40,177.29,177.05,176.99,167.47,167.39,153.71,153.60,153.22$, $153.10,152.29,152.14,152.11,151.87,151.78,151.23,151.21,151.18,146.95,146.37$, $146.25,144.12,143.25,143.16,143.05,142.94,142.46,142.37,142.22,142.14,140.95$, 139.20, 138.83, 138.73, 138.42, 138.37, 138.23, 138.19, 137.70, 137.57, 137.42, 137.21, 
$136.88,129.89,128.67,128.56,128.29,127.92,127.83,126.92,126.72,126.70,126.61$, $126.36,126.33,126.23,126.17,125.67,125.58,125.46,125.36,125.24,122.76,122.39$, $122.24,121.80,121.76,121.08,120.75,120.66,120.42,119.91,119.64,119.51,119.43$, $119.24,117.78,117.75,96.69,96.51,93.05,92.87,55.10,54.70,46.21,46.15,44.93$, $39.52,39.33,31.11,30.96,30.94,29.38,29.35,29.31,29.20,29.16,29.02,28.87,28.84$, $28.50,28.47,28.43,28.40,28.34,26.21,26.14,23.31,23.20,21.79,21.78,13.02,13.01$.

${ }^{11} \mathrm{~B}$ NMR $\left(\mathrm{CD}_{2} \mathrm{Cl}_{2}\right.$, ppm) $\delta$ 1.57. Positive ion MALDI-TOF-MS (Matrix : DIT): $\mathrm{m} / \mathrm{z}$ 1463.61820; found: m/z 1463.61696.

Lippert-Mataga plots. The Lippert equation:

$\mathrm{v}_{\mathrm{fl}}=\mathrm{v}_{\mathrm{ab}}-\frac{2 \Delta f}{\mathrm{hca}^{3}}\left(\mu_{\mathrm{E}}-\mu_{\mathrm{G}}\right)^{2}+$ const.

where h equals Planck's constant, c equals the velocity of light in a vacuum, a is the Onsager cavity radius, $n$ and $\varepsilon$ the refractive index and the dielectric constant of the solvent, $v_{\mathrm{fl}}$ and $v_{\mathrm{ab}}$ the fluorescence and absorption wavelength (expressed in $\mathrm{cm}^{-1}$ units), $\mu_{\mathrm{E}}$ and $\mu_{\mathrm{G}}$ the dipole moment (expressed in Debye units) in the excited and the ground state, respectively,

$\Delta f=\frac{\varepsilon-1}{2 \varepsilon+1}-\frac{\mathrm{n}^{2}-1}{4 \mathrm{n}^{2}+2}$

While the slope is

Slope $=-\frac{2 \Delta f}{\text { hca }^{3}}\left(\mu_{\mathrm{E}}-\mu_{\mathrm{G}}\right)^{2}$ 
Based on the calculation performed above, we can estimate that the excited state of dyes has a larger dipole moment than the ground state. 
Scheme S1. Synthetic scheme of the ligand $\mathbf{5}^{a}$
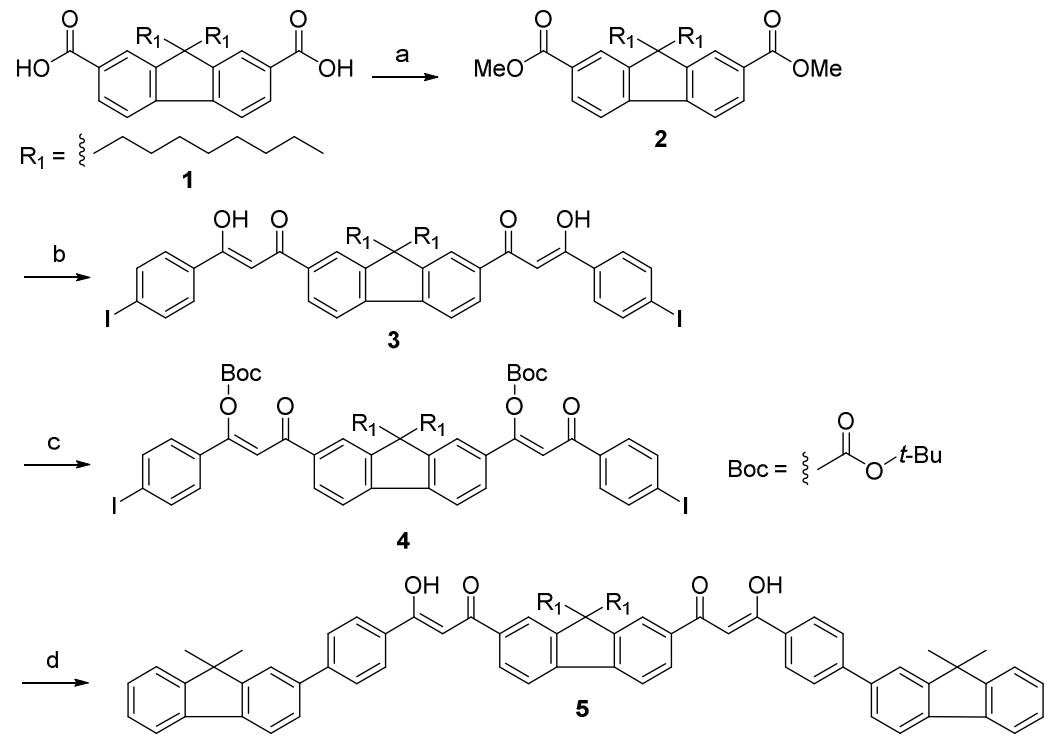

${ }^{a}$ Reagents and conditions: (a) conc. $\mathrm{H}_{2} \mathrm{SO}_{4}$, methanol, reflux, $16 \mathrm{~h}$; (b) p-iodoacetophenone, NaH, THF, $50{ }^{\circ} \mathrm{C}, \quad 16 \mathrm{~h} ; \quad$ (c) Boc $_{2} \mathrm{O}, \quad$ 2,4-dimethylaminopyridine, 1,4-dioxane, $40{ }^{\circ} \mathrm{C}, \quad 16 \quad \mathrm{~h} ; \quad$ (d) i) 9,9-dimethyl-9H-fluorene-2-yl-boronic acid, S-Phos, $\mathrm{Pd}_{2}(\mathrm{dba})_{3}, \mathrm{Cs}_{2} \mathrm{CO}_{3}$, toluene, water, $80{ }^{\circ} \mathrm{C}, 16 \mathrm{~h}$, ii) piperidine, dichloromethane, r.t., $16 \mathrm{~h}$. 
Scheme S2. Synthetic scheme of the Pt dimer ${ }^{a}$
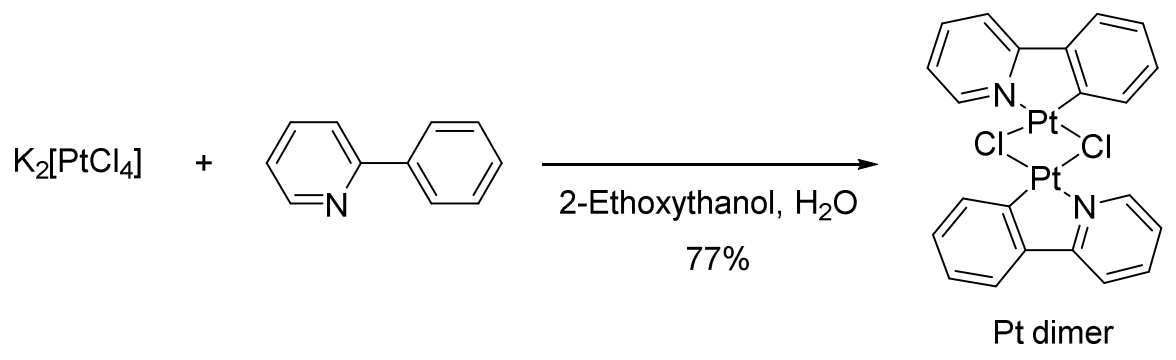

${ }^{a}$ conditions: $80^{\circ} \mathrm{C}, 6 \mathrm{~h}$ 


\section{Graphical Abstract}

Synthesis of Dual-Emissive Organometallic

Leave this area blank for abstract info.

Complexes Containing Heterogeneous Metal

Elements

Amane Hirose, Kazuo Tanaka*, Kenji Tamashima, Yoshiki Chujo*

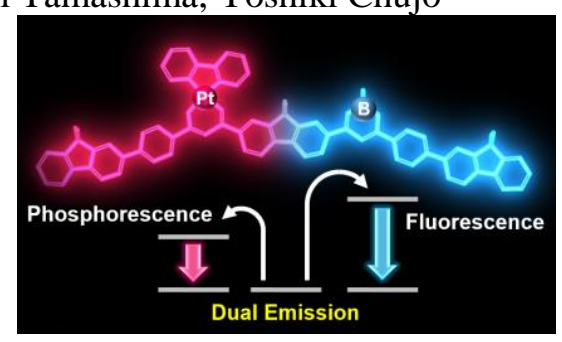


Tetrahedron Letters

journal homepage: www.elsevier.com

\title{
Synthesis of Dual-Emissive Organometallic Complexes Containing Heterogeneous Metal Elements
}

\author{
Amane Hirose, Kazuo Tanaka*, Kenji Tamashima, Yoshiki Chujo* \\ Department of Polymer Chemistry, Graduate School of Engineering, Kyoto University, Katsura, Nishikyo-ku, Kyoto 615-8510, Japan
}

\begin{abstract}
ARTICLE INFO
ABSTRACT

Article history:

Received

Received in revised form

Accepted

Available online

Keywords:

Organoboron complex

Diketonate

Platinum complex

We present the dual-emissive dye containing heterogeneous organometallic units-in the single molecule. The diad ligand composed of two diketonate moieties linked by fluorene was synthesized. By introducing boron and platinum elements, the emissive molecules were obtained. From optical measurements, it was confirmed that the boron and the platinumcontaining diads showed the emissions from the charge transfer and the triplet $\pi-\pi^{*}$ ligand centered transitions, respectively. Next, to observe these fluorescence and phosphorescence properties from the single-dye molecule, the diad composed of boron and platinum diketonates linked by the fluorene unit were prepared. Finally, the dual emission containing fluorescence from the boron complex and phosphorescence from the platinum complex was simultaneously observed.
\end{abstract}

Dual emission
2009 Elsevier Ltd. All rights reserved.
Dual-emissive materials have attracted attention because of their large potential for organic opto and/or electronic devices such as displays and optical chemosensors. For example, by loading the red, green, and blue chromophores into the polymeric matrices, the white-light emissive materials can be obtained. ${ }^{1-3}$ By modulating the feed ratio of each dye, the precise color tuning was accomplished. In these mixture systems, the suppression of the energy transfer is critical for obtaining the desired color and improving device efficiencies. As another instance, the optical sensor based on the fluorescent artificial nucleobase was presented for monitoring the structural alteration of DNA. ${ }^{4}$ The suppression of the molecular motion at the excited state provided the dual emission from the solution, resulting in the color change. Fräser et al. synthesized the dual-emissive molecules having both fluorescence and phosphorescence and successfully used them as the ratiometric oxygen sensor in the cells. ${ }^{5,6}$ From the intensity ratio between fluorescence and phosphorescence of the probe molecule, the concentration of the dissolved oxygen can be quantitatively estimated. Thus, the dual-emissive materials, especially single dye molecules, should be feasible in various fields. ${ }^{7-11}$ However, there are still much room to explore the strategy for preparing the dual-emissive single-molecules. Especially, to apply the dual emission as a practical material in material science as well as in the biotechnology, the establishment of the molecular design for dual-emissive molecules with the bottom up strategy is essential. It is necessary to construct a dual-emissive dye based on the rational design for a single molecule.

A wide variety of elements including main group elements, transition metals and lanthanide ions are capable to form a complex with the $\beta$-diketonate ligand. ${ }^{12-15}$ The optical properties of the diketonates are varied by the types of the coordinated elements. In particular, organometallic diketonate complexes presented various useful characteristics in the polymeric materials according to the recent reports. For instance, it is known that the organoboron-containing compounds showed various unique optical properties. ${ }^{16-21}$ Boron diketonates and their derivatives are also work as emissive dyes with large molar absorption coefficients and high fluorescence quantum yields. ${ }^{22-28}$ It has been demonstrated the modulation of optical properties by changing the complexation ratio of the diketonate ligands on the polymer main-chains. ${ }^{29}$ Boron diketonates work as a strong electron-acceptor. Significant emissions assigned as the intramolecular charge transfer (CT) states were obtained by increasing the introduction ratio of boron. In general, the CT state can be stabilized in the polar solvents, resulting in the red shift of the emission band. FinallyBased on this property, colorful emissive films were readily prepared from the single polymer structure only by changing the complexation ratio. It is known that the platinum complex with the diketonate ligand can show the strong phosphorescence. Swager et al. have reported that platinum diketonates with the expanded $\pi$-conjugation through the polymer main-chains showed the bright phosphorescence from a triplet $\pi-\pi^{*}$ ligand centered $\left({ }^{3} \mathrm{LC}\right)$ transition. ${ }^{30}$ These materials are applicable for improving the efficiencies of the recent opto and/or electric devices. ${ }^{31-39}$ According to these researches, it can be said that the organometallic diketonate ligands are versatile building blocks for constructing advanced optical materials. However, these organometallic diketonate complexes showed brilliant emissions and smart optical properties usually from the single type of moleculesmetal element. In particular, $t$ There are very few studies to evaluate the electronic interaction and optical properties of the diketonate 
complexes with the heterogeneous metal elements in the single

Scheme 1. Synthetic schemes of the diketonates compounds ${ }^{\mathrm{a}}$
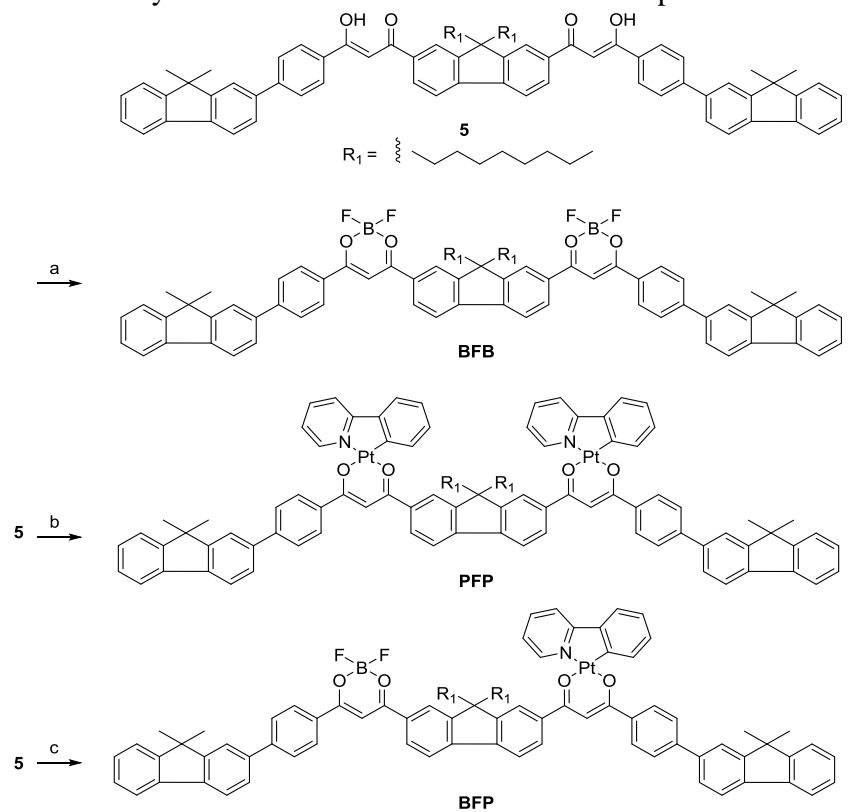

${ }^{a}$ Reagents and conditions: (a) $\mathrm{BF}_{3} \mathrm{OEt}_{2}$, dichloromethane, rt, 6 h; (b) Pt dimer, $\mathrm{Na}_{2} \mathrm{CO}_{3}$, 2-ethoxyethanol, $100{ }^{\circ} \mathrm{C}, 24 \mathrm{~h}$; (c) i) Pt dimer, $\mathrm{Na}_{2} \mathrm{CO}_{3}$, 2ethoxyethanol, $100{ }^{\circ} \mathrm{C}, 24 \mathrm{~h}$, ii) $\mathrm{BF}_{3} \cdot \mathrm{OEt}_{2}$, dichloromethane, r.t., $6 \mathrm{~h}$.

molecule.

Herein, we report the synthesis and the dual-emission properties of the single molecular type-dye composed of heterogeneous organometallic compounds. Initially, the optical properties of the dual-core diads with two boron or platinum diketonates linked with the fluorene unit were investigated. The two boron complexes-containing diad provided fluorescence from the intramolecular CT band, and the platinum-containing one showed phosphorescence from ${ }^{3} \mathrm{LC}$ band. Next, to realize the simultaneous detection of each emission from the different spin multiplicities, the emission of the organometallic compound with boron and platinum diketonates linked with fluorene was evaluated. Accordingly, we obtained dual emission composed of fluorescence from the boron complex moiety and phosphorescence from the platinum complex moiety. The feasible strategy can be presented not only for designing dualemissive compounds but also for obtaining the multi functions in the single $\underline{\text { single molecule. }}$

The synthetic outline of the complexes is shown in Scheme 1. Ligand $\mathbf{5}$ and boron diketonate BFB were prepared according to our previous work. ${ }^{29}$ To maintain the solubility of the diads, the 9 position at the center of the fluorene unit was modified with the alkyl chains. On the other hand, we found the steric hindrance of these alkyl chains crucially influenced on the yields in the palladium-catalyzed coupling reactions. When 2-ethylhexylsubstituted fluorene was used, the desired product was hardly obtained. Therefore, we used $n$-octyl groups in the diads. The formation of platinum diketonates was performed from $\mathbf{5}$ by the reaction with $\mathrm{Pt}$ dimer prepared with the Swager's report (Scheme S2). ${ }^{40}$ The boron platinum diketonate BFP was obtained via two steps from 5. The mono-substituted platinum complex was synthesized by treating with the 0.65 equivalent of Pt dimer. Subsequently, excess $\mathrm{BF}_{3} \cdot \mathrm{Et}_{2} \mathrm{O}$ solution was added to the monosubstituted complex. When boron complexation was carried out before the platinum introduction, a part of boron complexes were replaced to platinum complexes. The synthesized complexes were characterized by ${ }^{1} \mathrm{H},{ }^{13} \mathrm{C}$, and ${ }^{11} \mathrm{~B}$ NMR spectroscopies and mass measurements. Finally, we concluded that all products possessed the desired structures with enough purity for the
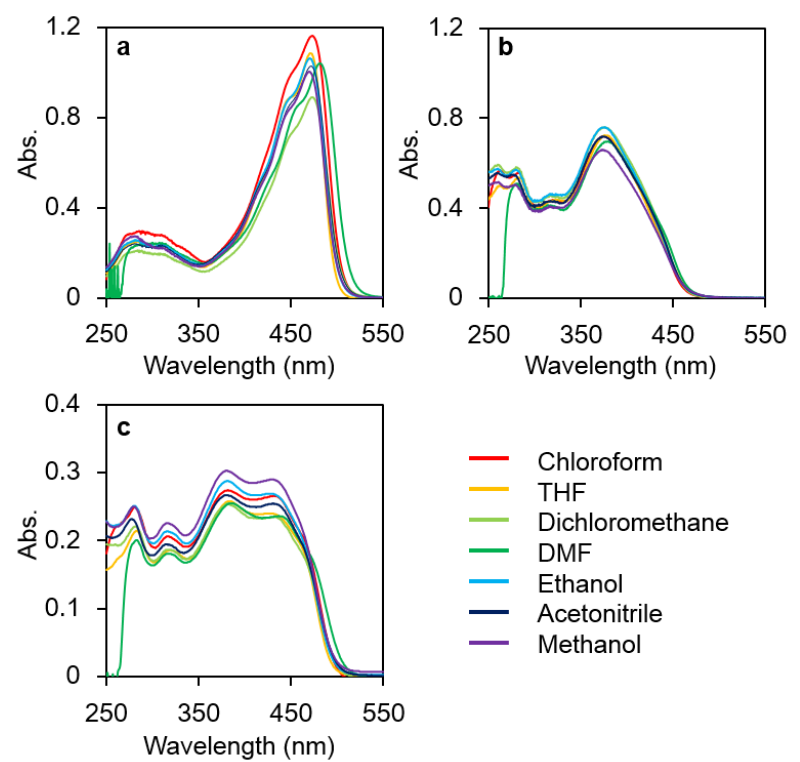

Figure 1. UV-vis spectra of (a) BFB, (b) PFP and (c) BFP in seven types of organic solvents $\left(1.0 \times 10^{-5} \mathrm{M}\right)$.
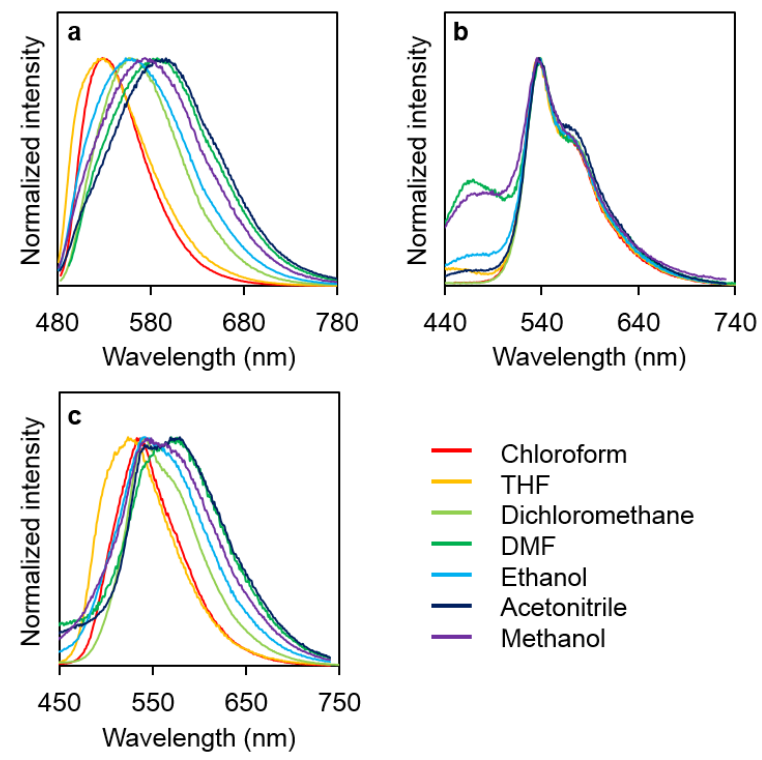

Figure 2. PL spectra of (a) BFB, (b) PFP and (c) BFP in seven organic solvents $\left(1.0 \times 10^{-5} \mathrm{M}\right)$ with the excitation light at the wavelength of the absorption maxima.

optical measurements.

To investigate the electronic structures of the synthesized complexes at the ground state, UV-vis absorption spectra were monitored in seven organic solvents (Figure 1). The results are summarized in Table 1. The largest absorption bands with the peaks at $460 \mathrm{~nm}$ and $370 \mathrm{~nm}$ assigned to the $\pi-\pi^{*}$ transitions at each complex were observed from BFB and PFP in all organic solvents, respectively. BFP showed significant absorption bands with the peaks around $440 \mathrm{~nm}$ and $380 \mathrm{~nm}$. The shape of the spectrum of BFP can be explained simply by mixing BFB and PFP. These data suggest that the electronic interaction between boron and platinum diketonates could be small. In other words, the optical properties of each complex could be intrinsically preserved by the center fluorene unit. The solvent effects were slightly observed from the spectra. These data mean that the 
perturbation of the electronic structures by the solvent molecules

lowered comparing to that of the ${ }^{3} \mathrm{CT}$ state by extending the conjugation of diketonate with the fluorene units, leading to the

Table 1. Photophysical properties of the diketonates in various kinds of solvents

\begin{tabular}{|c|c|c|c|c|c|c|c|c|c|}
\hline \multirow[b]{2}{*}{ Compound } & \multicolumn{3}{|c|}{ BFB } & \multicolumn{3}{|c|}{ PFP } & \multicolumn{3}{|c|}{ BFP } \\
\hline & $\Phi_{\mathrm{PL}}^{a}$ & $\begin{array}{c}\lambda_{\text {Abs,max }} \\
(\mathrm{nm})^{b}\end{array}$ & $\begin{array}{l}\lambda_{\mathrm{PL}, \max } \\
(\mathrm{nm})^{c}\end{array}$ & $\Phi_{\mathrm{PL}}^{a}$ & $\begin{array}{c}\lambda_{\text {Abs,max }} \\
(\mathrm{nm})^{b}\end{array}$ & $\begin{array}{l}\lambda_{\mathrm{PL}, \max } \\
(\mathrm{nm})^{c}\end{array}$ & $\Phi_{\mathrm{PL}}^{a}$ & $\begin{array}{c}\lambda_{\mathrm{Abs}} \\
(\mathrm{nm})^{b}\end{array}$ & $\begin{array}{c}\lambda_{\mathrm{PL}} \\
(\mathrm{nm})^{c}\end{array}$ \\
\hline chloroform & 0.78 & 474 & 529 & 0.04 & 374 & 538 & 0.07 & 381,432 & 533 \\
\hline THF & 0.61 & 472 & 531 & 0.01 & 380 & 538 & 0.04 & 383,426 & 525 \\
\hline dichloromethane & 0.59 & 474 & 557 & 0.05 & 376 & 539 & 0.06 & 381,431 & 540 \\
\hline DMF & 0.01 & 483 & 588 & $<0.01$ & 380 & 539 & 0.01 & 385,437 & 573 \\
\hline ethanol & 0.10 & 471 & 560 & 0.01 & 377 & 538 & 0.02 & 381,428 & 541 \\
\hline acetonitrile & 0.01 & 473 & 597 & 0.01 & 373 & 537 & 0.01 & 380,430 & 541,579 \\
\hline methanol & 0.03 & 471 & 574 & $<0.01$ & 374 & 535 & 0.01 & 381,429 & 544 \\
\hline
\end{tabular}

${ }^{\mathrm{a}}$ Absolute quantum yield.

${ }^{b}$ Measured in the solution $\left(1.0 \times 10^{-5} \mathrm{M}\right)$.

${ }^{\mathrm{c}}$ Measured in the solution $\left(1.0 \times 10^{-5} \mathrm{M}\right)$ with the excitation light at the maximum peak wavelength of absorption.

Table 2. Stokes shift and life time of the diketonates in various kinds of solvents

\begin{tabular}{|c|c|c|c|c|c|}
\hline \multirow{2}{*}{ Compound } & \multicolumn{2}{|c|}{ BFB } & \multicolumn{2}{|c|}{ PFP } & \multirow{2}{*}{$\frac{\text { BFP }}{\tau(\mathrm{ns})^{a}}$} \\
\hline & Stokes shift $\left(\mathrm{cm}^{-1}\right)$ & $\tau(\mathrm{ns})^{a}$ & Stokes shift $\left(\mathrm{cm}^{-1}\right)$ & $\tau(\mathrm{ns})^{a}$ & \\
\hline chloroform & 2190 & 1.78 & 8150 & 426 & $1.96,308^{b}$ \\
\hline THF & 2350 & 1.70 & 7730 & $12.6(17 \%), 31.7(83 \%)$ & $\begin{array}{l}1.70(88 \%), 3.11(12 \%) \\
161(17 \%)^{b}, 353(83 \%)^{b}\end{array}$ \\
\hline dichloromethane & 3140 & 1.96 & 8040 & 508 & $\begin{array}{c}2.06 \\
190(23 \%)^{b}, 342(77 \%)^{b}\end{array}$ \\
\hline DMF & 3670 & $0.105(7 \%), 0.999(93 \%)$ & 7760 & $\begin{array}{c}0.434(5 \%) \\
2.60(21 \%), 6.89(74 \%)\end{array}$ & $\begin{array}{c}0.619(17 \%), 1.77(74 \%) \\
6.70(9 \%)\end{array}$ \\
\hline ethanol & 3370 & $0.315(20 \%), 1.08(80 \%)$ & 7940 & $14.8(22 \%), 35.5(78 \%)$ & $1.76(77 \%), 20.4(23 \%)$ \\
\hline acetonitrile & 4390 & $0.100(3 \%), 0.836(97 \%)$ & 8190 & $27.2(27 \%), 54.1(73 \%)$ & $0.144(56 \%), 29.8(44 \%)$ \\
\hline methanol & 3809 & $0.757(45 \%), 3.10(55 \%)$ & 8050 & $1.72(16 \%), 16.2(84 \%)$ & $0.967(83 \%), 10.7(17 \%)$ \\
\hline
\end{tabular}

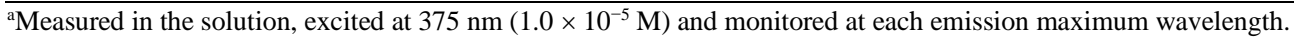

bobserved in the longer delay time regions.

such as coordination or protonation should hardly occur.

The electronic structures of the diketonates at the excited states were evaluated. Initially, the emission behavior of BFB was examined (Figure 2a). The PL spectra of BFB were measured in chloroform, THF, dichloromethane, DMF, ethanol, acetonitrile, and methanol with the excitation light at the peaks determined from absorption spectra (Table 2). As presented in the previous report, the optical property of BFB corresponded to the typical behavior as a CT emission. ${ }^{29}$ The bathochromic shift and the decreases of the emission intensity were observed by increasing solvent polarity. In chloroform, BFB showed strong emission with the peak at $529 \mathrm{~nm}$ with high emission efficiency (emission quantum yield, $\Phi=0.78$ ). In contrast, in acetonitrile, the emission band was observed in the red-shifted region with the peak at $597 \mathrm{~nm}$ with low efficiency $(\Phi=0.01)$. According to the Lippert-Mataga plots prepared from BFB, the linear relationship between the solvent polarity and the Stokes shifts was obtained (Figure 3a). The lifetime of BFB was about 1 3 ns in each solvent. These changes are the typical behavior as the fluorescence emission from the CT band.

The emission mechanism of PFP was investigated. PFP exhibited emission bands with the peaks around $540 \mathrm{~nm}$ in all organic solvents (Figures 2 b). In particular, the significant peak shifts of the emission bands were less observed. Indeed, the less solvent effect was reflected in Lippert-Mataga plots (Figure 3b). The much longer lifetime (426 ns) was observed in chloroform comparing to that of BFB. This result indicates that the emission should be phosphorescence. In addition, the significant changes were observed from the PL spectra at $77 \mathrm{~K}$ in the glassy state (Figure 4). It is known that the metal-to-ligand CT-based transitions should be critically influenced from the solvent molecules because of large reorganization energies in the polar solvents or rigid media. ${ }^{41}$ These results indicate that the emission of PFP should be derived from the ${ }^{3} \mathrm{LC}$ transition. Similarly to the Swager's system, energy level of the ${ }^{3} \mathrm{LC}$ state could be
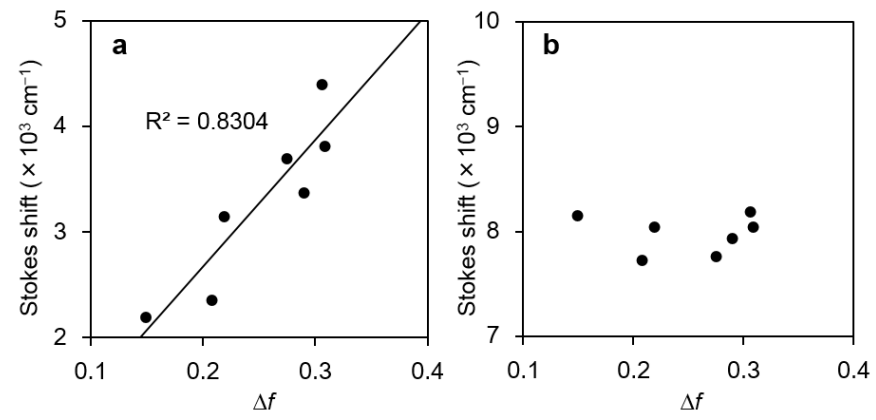

Figure 3. Lippert-Mataga plots of (a) BFB and (b) PFP. The protocols were shown in the Supporting Information.

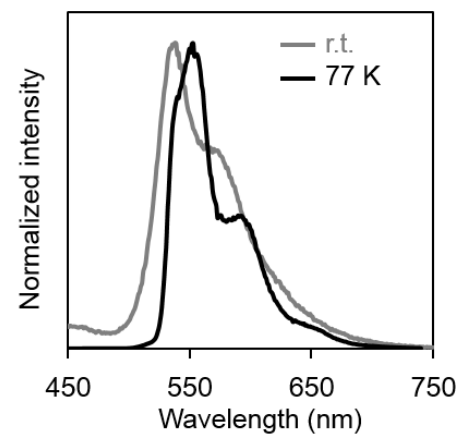

Figure 4. PL spectra of PFP in THF at room temperature (gray line) and in 2-methyl THF at 77K (black line).

phosphorescence from the ${ }^{3} \mathrm{LC}$ transition. ${ }^{40}$

Finally, we evaluated the optical properties of BFP. Notably, the PL spectrum of BFP in acetonitrile exhibited two peaks at $541 \mathrm{~nm}$ and $579 \mathrm{~nm}$ (Figure 2). This result clearly indicates that BFP is the dual-emissive dye. To assign each emission band, we analyzed the optical properties. In contrast to PFP, the shape of the emission spectrum of BFP seemed to be affected by solvent polarity in the excited states. Although the two peaks were 

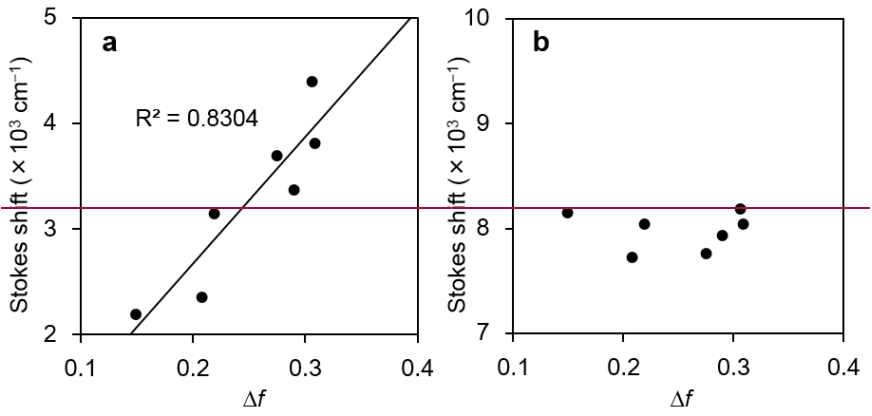

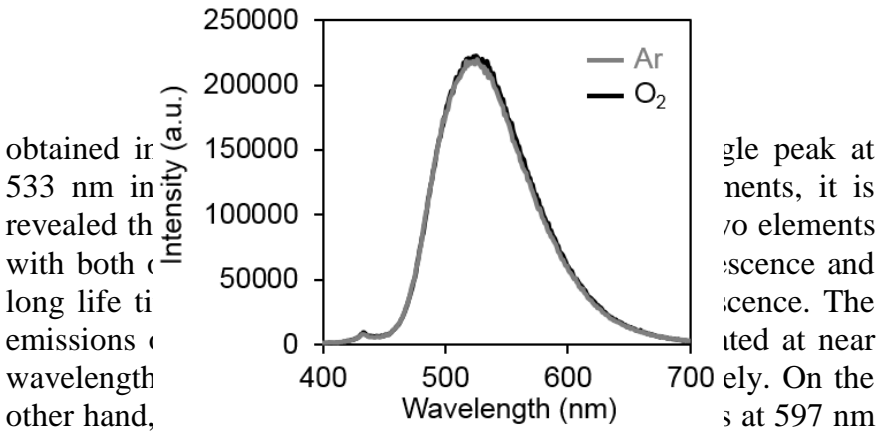
and $537 \mathrm{~nm}$ in acetonitrile, respectively. From these results, it can be summarized that BFP has dual emission properties composed of the fluorescence from boron diketonate and the phosphorescence from platinum diketonate. The emission of BFP is composed of the overlapping emissions of BFB and PFP. It should be notified that the phosphorescence emission of BFP was hardly influenced by the oxygen concentration (Figure 5). Even after oxygen bubbling through the solution, the magnitude of phosphorescence was maintained. Steric hindrance of alkyl chains at the center fluorene unit could contribute to the preservation of the emissions from both complexes.

We present the synthesis of the diketonate-based diads composed of heterogeneous organometallic complexes. The dual emissions were observed from the synthesized dyes by individually obtaining the emissions from each organometallic complex. This study involves two significant issues: The synthetic procedures for the tandem complexation with boron and platinum elements to the diketonate ligand were established. Because of a wide versatility of boron and platinum diketonates in the optical materials, useful information on the synthesis of the complexes can be provided. Secondly, we present the isolation effect of the fluorene unit in the middle of conjugation system, leading to the dual emissions with fluorescence and phosphorescence. Although the fluorescence quantum yields of boron diketonates were reduced by the heavy atom effectintroduction of platinum, the mixing spectra with the emissions generated from the different spin multiplicities were obtained. Our findings described here could be applicable for exploiting further combinations with different pairs of metal elements.

\section{Acknowledgments}

This work was partially supported by the JFE 21st Century Foundation (for K.T.), "the Adaptable and Seamless Technology Transfer Program" through target-driven R\&D, Japan Science and Technology Agency (JST) and a Grant-in-Aid for Scientific Research on Innovative Areas "New Polymeric Materials Based on Element-Blocks (No.2401)" (24102013) of The Ministry of Education, Culture, Sports, Science, and Technology, Japan.

\section{References and notes}

1. Wu, H.; Ying, L.; Yang, W.; Cao, Y. Chem. Soc. Rev. 2009, 38, 3391-3400.

2. $\quad \mathrm{Bu}, \mathrm{J} . ;$ Watanabe, K.; Hayasaka, H.; Akagi, K. Nat. Commun 2014, 5, DOI: $10.1038 /$ ncomms4799.

3. Kajiwara, Y.; Nagai, A.; Tanaka, K.; Chujo, Y. J. Mater. Chem. C 2013, 1, 4437-4444.

4. Okamoto, A.; Tainaka, K.; Nishiza, K.; Saito, I. J. Am. Chem. Soc. 2005, 127, 13128-13129.

5. Palmer, G. M.; Fontanella, A. N.; Zhang, G.; Hanna, G.; Fraser, C. L.; Dewhirst, M. W. J. Biomed. Opt. 2010, 15, 066021.

6. Zhang, G.; Palmer, G. M.; Dewhirst, M. W.; Fraser, C. L. Nat. Mater. 2009, 8, 747-751.

7. Morimoto, T.; Ito, M.; Koike, K.; Kojima, T.; Ozeki, T.; Ishitani, O. Chem. Eur. J. 2012, 18, 3292-3304.

8. Hudson, Z. M.; Zhao, S.-B.; Wang, R.-Y.; Wang, S. Chem. Eur. J. 2009, 15, 6131-6137.

9. Liu, Y.; Guo, H.; Zhao, J. Chem. Commun., 2011, 47, 11471-11473.

10. Suzuki, T.; Kuchiyama, T.; Kishi, S.; Kaizaki, S.; Takagi, H. D.; Kato, M. Inorg. Chem. 2003, 42, 785-795.

11. Inoue, Y.; Jiang, P.; Tsukada, E.; Wada, T.; Shimizu, H.; Tai, A.; Ishikawa, M. J. Am. Chem. Soc. 2002, 124, 6942-6949.

12. Otway, D. J.; Rees, W. S., Jr. Coord. Chem. Rev. 2000, 210 , 279-328.

13. Marciniak, B.; Buono-Core, G. E. J. Photochem. Photobiol., A 1990, 52, 1-25.

14. Liu, S.-J.; Chen, Y.; Xu, W.-J.; Zhao, Q.; Huang, W. Macromol. Rapid Commun. 2012, 33, 461-480.

15. Binnemans, K. Handbook on the Physics and Chemistry of Rare Earths 2005, 35, pp. 107-272.

16. Tanaka, K.; Chujo, Y. Macromol. Rapid Commun. 2012, 33, 1235-1255.

17. Yoshii, R.; Nagai, A.; Tanaka, K.; Chujo, Y. J. Polym. Sci. Part A: Polym. Chem. 2013, 51, 1726-1733.

18. Tanaka, K.; Yamane, H.; Yoshii, R.; Chujo, Y. Bioorg. Med. Chem. 2013, 21, 2715-2719.

19. Yeo, H.; Tanaka, K.; Chujo, Y. Macromolecules 2013, 46, 2599 2605.

20. Yoshii, R.; Yamane, H.; Nagai, A.; Tanaka, K.; Taka, H.; Kita, H.; Chujo, Y. Macromolecules 2014, 47, 2316-2323.

21. Yoshii, R.; Yamane, H.; Tanaka, K.; Chujo, Y. Macromolecules 2014, 47, 3755-3760.

22. Maeda, H.; Mihashi, Y.; Haketa, Y. Org. Lett. 2008, 10, 3179-3182.

23. Ono, K.; Yoshikawa, K.; Tsuji, Y.; Yamaguchi, H.; Uozumi, R.; Tomura, M.; Taga, K.; Saito, K. Tetrahedron 2007, 63, 9354-9358.

24. Zhang, G.; Chen, J.; Payne, S. J.; Kooi, S. E.; Demas, J. N.; Fraser, C. L. J. Am. Chem. Soc. 2007, 129, 8942-8943.

25. Yoshii, R.; Nagai, A.; Tanaka, K.; Chujo, Y. Chem. Eur. J. 2013, 19, 4506-4512.

26. Yoshii, R.; Tanaka, K.; Chujo, Y. Macromolecules 2014, 47, 2268-2278.

27. Yoshii, R.; Nagai, A.; Tanaka, K.; Chujo, Y. Macromol. Rapid Commun. 2014, 35, 1315-1319.

28. Yoshii, R.; Hirose, A.; Tanaka, K.; Chujo, Y. Chem. Eur. J. 2014, $20,8320-8324$.

29. Tanaka, K.; Tamashima, K.; Nagai, A.; Okawa, T.; Chujo, Y. Macromolecules 2013, 46, 2969-2975.

30. Thomas, S. W., III.; Yagi, S.; Swager, T. M. J. Mater. Chem. 2005, 15, 2829-2835.

31. Nagai, A.; Kokado, K.; Nagata, Y.; Chujo, Y. Macromolecules 2008, 41, 8295-8298.

32. Cogné-Laage, E.; Allemand, J.-F.; Ruel, O.; Baudin, J.-B.; Croquette, V.; Blanchard-Desce, M.; Jullien, L. Chem. Eur. J. 2004, 10, 1445-1455.

33. Wong, W.-Y.; Wang, X.-Z.; He, Z.; Djurišić, A. B.; Yip, C.-T.; Cheung, K.-Y.; Wang, H.; Mak, C. S. K.; Chan, W.-K. Nat. Mater. 2007, 6, 521-527.

34. Zhang, W.; Fang, Z.; Su, M.; Saeys, M.; Liu, B. Macromol. Rapid Commun. 2009, 30, 1533-1537.

35. Wang, Q.; Wong, W.-Y. Polym. Chem. 2011, 2, 432-440.

36. D'Andrade, B. W.; Thompson, M. E.; Forrest, S. R. Adv. Mater. 2002, 14, 147-151. 
37. Adamovich, V.; Brooks, J.; Tamayo, A.; Alexander, A. M.;

Djurovich, P., I.; D’Andrade, B.; Adachi, C.; Forrest, S. R.;

Thompson, M. E. New J. Chem. 2002, 26, 1171-1178.

38. Shigehiro, T.; Yagi, S.; Maeda, T.; Nakazumi, H.; Fujiwara, H.

Sakurai, Y. J. Phys. Chem. C 2013, 117, 532-542.

39. Furuta, P. T.; Deng, L.; Garon, S.; Thompson, M. E.; Fréchet, J. M.

J. J. Am. Chem. Soc. 2004, 126, 15388-15389.

40. Godbert, N.; Pugliese, T.; Aiello, I.; Bellusci, A.; Crispini, A.;

Ghedini, M. Eur. J. Inorg. Chem. 2007, 5105-5111.

41. Glusac, K. D.; Jiang, S.; Schanze, K. S. Chem. Commun. 2002, 2504-2505. 